4

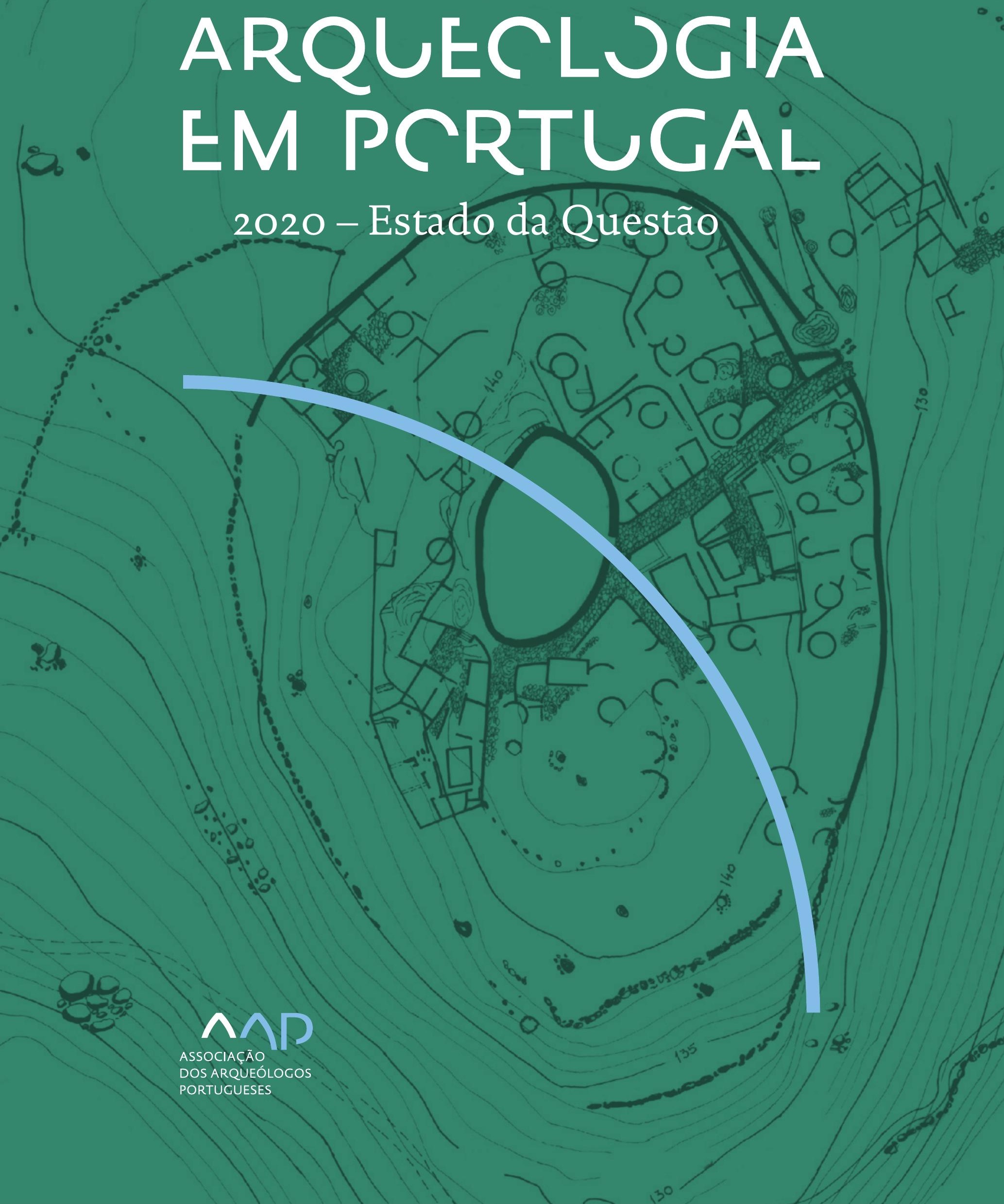


Coordenação editorial: José Morais Arnaud, César Neves e Andrea Martins Design gráfico: Flatland Design

AAP - ISBN: 978-972-9451-89-8

CITCEM - ISBN: 978-989-8970-25-1

Associação dos Arqueólogos Portugueses e CITCEM

Lisboa, 2020

O conteúdo dos artigos é da inteira responsabilidade dos autores. Sendo assim a Associação dos Arqueólogos Portugueses declina qualquer responsabilidade por eventuais equívocos ou questões de ordem ética e legal.

Desenho de capa:

Planta do castro de Monte Mozinho (Museu Municipal de Penafiel).

\section{$\hat{\wedge} \mathrm{P}$}

DOS ARQUEÓLOGOS PORTUGUESES

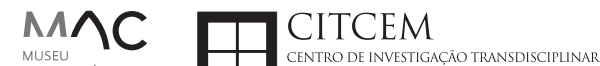
MUSEU
ARQUELLÓGICO
DO CARMO
U.PORTO

FLUP FACULDADE DE LETRAS
UNIVERSIDADE DO PORTO

Apoio

EC para a Ciência 


\section{Índice}

15 Prefácio

José Morais Arnaud

\section{Historiografia e Teoria}

17 Território, comunidade, memória e emoção: a contribuição da história da arqueologia (algumas primeiras e breves reflexões)

Ana Cristina Martins

25 Como descolonizar a arqueologia portuguesa?

Rui Gomes Coelho

41 Arqueologia e Modernidade: uma revisitação pessoal e breve de alguns aspetos da obra homónima de Julian Thomas de 2004

Vítor Oliveira Jorge

57 Dados para a História das Mulheres na Arqueologia portuguesa, dos finais do século XIX aos inícios do século XX: números, nomes e tabelas

Filipa Dimas / Mariana Diniz

73 Retractos da arqueologia portuguesa na imprensa: (in)visibilidades no feminino

Catarina Costeira / Elsa Luís

85 Arqueologia e Arqueólogos no Norte de Portugal Jacinta Bugalhão

101 Vieira Guimarães (1864-1939) e a arqueologia em Tomar: uma abordagem sobre o território e as gentes

João Amendoeira Peixoto / Ana Cristina Martins

115 Os memoráveis? A arqueologia algarvia na imprensa nacional e regional na presente centúria (2001-2019): características, visões do(s) passado(s) e a arqueologia

enquanto marca

Frederico Agosto / João Silva

129 A Evolução da Arqueologia Urbana e a Valorização Patrimonial no Barlavento Algarvio: Os casos de Portimão e Silves

Artur Mateus / Diogo Varandas / Rafael Boavida

\section{Gestão, Valorização e Salvaguarda do Património}

145 O Caderno Reivindicativo e as condições de trabalho em Arqueologia Miguel Rocha / Liliana Matias Carvalho / Regis Barbosa / Mauro Correia / Sara Simões / Jacinta Bugalhão / Sara Brito / Liliana Veríssimo Carvalho / Richard Peace / Pedro Peça / Cézer Santos

155 Os Estudos de Impacte Patrimonial como elemento para uma estratégia sustentável de minimização de impactes no âmbito de reconversões agrícolas Tiago do Pereiro

165 Salvaguarda de Património arqueológico em operações florestais: gestão e sensibilização Filipa Bragança / Gertrudes Zambujo / Sandra Lourenço / Belém Paiva / Carlos Banha / Frederico Tatá Regala / Helena Moura / Jacinta Bugalhão / João Marques / José Correia / Pedro Faria / Samuel Melro

179 Os valores do Património: uma investigação sobre os Sítios Pré-históricos de Arte Rupestre do Vale do Rio Côa e de Siega Verde José Paulo Francisco 
189 Conjugando recursos arqueológicos e naturais para potenciar as visitas ao Geoparque Litoral de Viana do Castelo (Noroeste de Portugal)

Hugo A. Sampaio / Ana M.S. Bettencourt / Susana Marinho / Ricardo Carvalhido

203 Áreas de Potencial Arqueológico na Região do Médio Tejo: Modelo Espacial Preditivo Rita Ferreira Anastácio / Ana Filipa Martins / Luiz Oosterbeek

223 Património Arqueológico e Gestão Territorial: O contributo da Arqueologia para a revisão do PDM de Avis

Ana Cristina Ribeiro

237 A coleção arqueológica do extinto Museu Municipal do Porto - Origens, Percursos e Estudos

Sónia Couto

251 Valpaços - uma nova carta arqueológica

Pedro Pereira / Maria de Fátima Casares Machado

263 Arqueologia na Cidade de Peniche

Adriano Constantino / Luís Rendeiro

273 Arqueologia Urbana: a cidade de Lagos como caso de Estudo Cátia Neto

285 Estratégias de promoção do património cultural subaquático nos Açores. O caso da ilha do Faial

José Luís Neto / José Bettencourt / Luís Borges / Pedro Parreira

297 Carta Arqueológica da Cidade Velha: Uma primeira abordagem

Jaylson Monteiro / Nireide Tavares / Sara da Veiga / Claudino Ramos / Edson Brito /

Carlos Carvalho / Francisco Moreira / Adalberto Tavares

311 Antropologia Virtual: novas metodologias para a análise morfológica e funcional Ricardo Miguel Godinho / Célia Gonçalves

\section{Didáctica da Arqueologia}

327 Como os projetos de Arqueologia podem contribuir para uma comunidade culturalmente mais consciente Alexandra Figueiredo / Claúdio Monteiro / Adolfo Silveira / Ricardo Lopes

337 Educação Patrimonial - Um cidadão esclarecido é um cidadão ativo! Ana Paula Almeida

351 A aproximação da Arqueologia à sala de aula: um caso de estudo no $3^{\circ}$ ciclo do Ensino Básico Luís Serrão Gil

363 Arqueologia 3.o - Pensar e comunicar a Arqueologia para um futuro sustentável Mónica Rolo

377 “Conversa de Arqueólogos" - Divulgar a Arqueologia em tempos de Pandemia Diogo Teixeira Dias

389 Escola Profissional de Arqueologia: desafios e oportunidades Susana Nunes / Dulcineia Pinto / Júlia Silva / Ana Mascarenhas

399 Os Museus de Arqueologia e os Jovens: a oferta educativa para o público adolescente Beatriz Correia Barata / Leonor Medeiros

411 O museu universitário como mediador entre a ciência e a sociedade: o exemplo da secção de arqueologia no Museu de História Natural e da Ciência da Universidade do Porto (MHNC-UP)

Rita Gaspar 
421 Museu de Lanifícios: Real Fábrica de Panos. Atividades no âmbito da Arqueologia Beatriz Correia Barata / Rita Salvado

427 Arqueologia Pública e o caso da localidade da Mata (Torres Novas) Cláudia Manso / Ana Rita Ferreira / Cristiana Ferreira / Vanessa Cardoso Antunes

431 Do sítio arqueológico ao museu: um percurso (também) didático Lídia Fernandes

447 Estão todos convidados para a Festa! E para dançar também... O projecto do Serviço Educativo do Museu Arqueológico do Carmo na $5^{\underline{a}}$ Edição da Festa da Arqueologia Rita Pires dos Santos

459 O “Clã de Carenque”, um projeto didático de arqueologia Eduardo Gonzalez Rocha

469 Mediação cultural: peixe que puxa carroça nas Ruínas Romanas de Troia Inês Vaz Pinto / Ana Patrícia Magalhães / Patrícia Brum / Filipa Santos

481 Didática Arqueológica, experiências do Projeto Mértola Vila Museu Maria de Fátima Palma / Clara Rodrigues / Susana Gómez / Lígia Rafael

\section{Arte Rupestre}

497 Os inventários de arte rupestre em Portugal Mila Simões de Abreu

513 O projeto FIRST-ART - conservação, documentação e gestão das primeiras manifestações de arte rupestre no Sudoeste da Península Ibérica: as grutas do Escoural e Maltravieso Sara Garcês / Hipólito Collado / José Julio García Arranz / Luiz Oosterbeek / António Carlos Silva / Pierluigi Rosina / Hugo Gomes / Anabela Borralheiro Pereira / George Nash / Esmeralda Gomes / Nelson Almeida / Carlos Carpetudo

523 Trabalhos de documentação de arte paleolítica realizados no âmbito do projeto PalæoCôa André Tomás Santos / António Fernando Barbosa / Luís Luís / Marcelo Silvestre / Thierry Aubry

537 Imagens fantasmagóricas, silhuetas elusivas: as figuras humanas na arte do Paleolítico Superior da região do Côa Mário Reis

$55^{1}$ Os motivos zoomórficos representados nas placas de tear de Vila Nova de São Pedro (Azambuja, Portugal) Andrea Martins / César Neves / José M. Arnaud / Mariana Diniz

571 Arte Rupestre do Monte de Góios (Lanhelas, Caminha). Síntese dos resultados dos trabalhos efectuados em 2007-2009 Mário Varela Gomes

599 Gravuras rupestres de barquiformes no Monte de S. Romão, Guimarães, Noroeste de Portugal Daniela Cardoso

613 Círculos segmentados gravados na Bacia do Rio Lima (Noroeste de Portugal): contributos para o seu estudo Diogo Marinho / Ana M.S. Bettencourt / Hugo Aluai Sampaio

631 Equídeos gravados no curso inferior do Rio Mouro, Monção (NW Portugal). Análise preliminar Coutinho, L.M. / Bettencourt, A.M.S / Sampaio, Hugo A.S

645 Paletas na Arte Rupestre do Noroeste de Portugal. Inventário preliminar Bruna Sousa Afonso / Ana M. S. Bettencourt / Hugo A. Sampaio 


\section{Pré-História}

661 O projeto Miño/Minho: balanço de quatro anos de trabalhos arqueológicos Sérgio Monteiro-Rodrigues / João Pedro Cunha-Ribeiro / Eduardo Méndez-Quintas / Carlos Ferreira / Pedro Xavier / José Meireles / Alberto Gomes / Manuel Santonja / Alfredo Pérez-González

677 A ocupação paleolítica da margem esquerda do Baixo Minho: a indústria lítica do sítio de Pedreiras 2 (Monção, Portugal) e a sua integração no contexto regional Carlos Ferreira / João Pedro Cunha-Ribeiro / Sérgio Monteiro-Rodrigues / Eduardo Méndez-Quintas / Pedro Xavier / José Meireles / Alberto Gomes / Manuel Santonja / Alfredo Pérez-González

693 O sítio acheulense do Plistocénico médio da Gruta da Aroeira Joan Daura / Montserrat Sanz / Filipa Rodrigues / Pedro Souto / João Zilhão

703 As sociedades neandertais no Barlavento algarvio: modelos preditivos com recurso aos SIG

Daniela Maio

715 A utilização de quartzo durante o Paleolítico Superior no território dos vales dos rios Vouga e Côa

Cristina Gameiro / Thierry Aubry / Bárbara Costa / Sérgio Gomes / Luís Luís / Carmen Manzano / André Tomás Santos

733 Uma perspetiva diacrónica da ocupação do concheiro do Cabeço da Amoreira (Muge, Portugal) a partir da tecnologia lítica Joana Belmiro / João Cascalheira / Célia Gonçalves

745 Novos dados sobre a Pré-história Antiga no concelho de Palmela. A intervenção arqueológica no sítio do Poceirão I

Michelle Teixeira Santos

757 Problemas em torno de Datas Absolutas Pré-Históricas no Norte do Alentejo Jorge de Oliveira

771 Povoamento pré-histórico nas áreas montanhosas do NO de Portugal: o Abrigo 1 de Vale de Cerdeira Pedro Xavier / José Meireles / Carlos Alves

783 Apreciação do povoamento do Neolítico Inicial na Baixa Bacia do Douro. A Lavra I (Serra da Aboboreira) como caso de estudo Maria de Jesus Sanches

797 O Processo de Neolitização na Plataforma do Mondego: os dados do Sector C do Outeiro dos Castelos de Beijós (Carregal do Sal)

João Carlos de Senna-Martinez / José Manuel Quintã Ventura / Andreia Carvalho / Cíntia Maurício

823 Novos trabalhos na Lapa da Bugalheira (Almonda, Torres Novas) Filipa Rodrigues / Pedro Souto / Artur Ferreira / Alexandre Varanda / Luís Gomes / Helena Gomes / João Zilhão

837 A pedra polida e afeiçoada do sítio do Neolítico médio da Moita do Ourives (Benavente, Portugal)

César Neves

857 Casal do Outeiro (Encarnação, Mafra): novos contributos para o conhecimento do povoamento do Neolítico final na Península de Lisboa.

Cátia Delicado / Carlos Maneira e Costa / Marta Miranda / Ana Catarina Sousa

873 Stresse infantil, morbilidade e mortalidade no sítio arqueológico do Neolítico Final/ Calcolítico ( $4^{\circ}$ e $3^{\circ}$ milénio a.C.) do Monte do Carrascal 2 (Ferreira do Alentejo, Beja) Liliana Matias de Carvalho / Sofia N. Wasterlain 
885 Come together: O Conjunto Megalítico das Motas (Monção, Viana do Castelo) e as expressões Campaniformes do Alto Minho Ana Catarina Basílio / Rui Ramos

899 Trabalhos arqueológicos no sítio Calcolítico da Pedreira do Poio Carla Magalhães / João Muralha / Mário Reis / António Batarda Fernandes

913 O sítio arqueológico de Castanheiro do Vento. Da arquitectura do sítio à arquitectura de um território João Muralha Cardoso

925 Estudo zooarqueológico das faunas do Calcolítico final de Vila Nova de São Pedro (Azambuja, Portugal): Campanhas de 2017 e 2018 Cleia Detry / Ana Catarina Francisco / Mariana Diniz / Andrea Martins / César Neves / José Morais Arnaud

943 As faunas depositadas no Museu Arqueológico do Carmo provenientes de Vila Nova de São Pedro (Azambuja): as campanhas de 1937 a 1967 Ana Catarina Francisco / Cleia Detry / César Neves / Andrea Martins / Mariana Diniz / José Morais Arnaud

959 Análise funcional de material lítico em sílex do castro de Vila Nova de S. Pedro (Azambuja, Portugal): uma primeira abordagem Rafael Lima

971 O recinto da Folha do Ouro 1 (Serpa) no contexto dos recintos de fossos calcolíticos alentejanos

António Carlos Valera / Tiago do Pereiro / Pedro Valério / António M. Monge Soares

\section{Proto-História}

987 Produção de sal marinho na Idade do Bronze do noroeste Português. Alguns dados para uma reflexão

Ana M. S. Bettencourt / Sara Luz / Nuno Oliveira / Pedro P. Simões / Maria Isabel C. Alves / Emílio Abad-Vidal

1001 A estátua-menir do Pedrão ou de São Bartolomeu do Mar (Esposende, noroeste de Portugal) no contexto arqueológico da fachada costeira de entre os rios Neiva e Cávado Ana M. S. Bettencourt / Manuel Santos-Estévez / Pedro Pimenta Simões / Luís Gonçalves

1015 O Castro do Muro (Vandoma/Baltar, Paredes) - notas para uma biografia de ocupação da Idade do Bronze à Idade Média

Maria Antónia D. Silva / Ana M. S. Bettencourt / António Manuel S. P. Silva / Natália Félix

1031 Do Bronze Final à Idade Média - continuidades e hiatos na ocupação de Povoados em Oliveira de Azeméis João Tiago Tavares / Adriaan de Man

1041 As faunas do final da Idade do Bronze no Sul de Portugal: leituras desde o Outeiro do Circo (Beja)

Nelson J. Almeida / Íris Dias / Cleia Detry / Eduardo Porfírio / Miguel Serra

1055 A Espada do Monte das Oliveiras (Serpa) - uma arma do Bronze Pleno do Sudoeste Rui M. G. Monge Soares / Pedro Valério / Mariana Nabais / António M. Monge Soares

1065 São Julião da Branca (Albergaria-a-Velha) - Investigação e valorização de um povoado do Bronze Final

António Manuel S. P. Silva / Paulo A. P. Lemos / Sara Almeida e Silva / Edite Martins de Sá

1083 Do castro de S. João ao Mosteiro de Santa Clara: notícia de uma intervenção arqueológica, em Vila do Conde Rui Pinheiro 
1095 O castro de Ovil (Espinho), um quarto de século de investigação - resultados e questões em aberto

Jorge Fernando Salvador / António Manuel S. P. Silva

1111 O Castro de Salreu (Estarreja), um povoado proto-histórico no litoral do Entre Douro e Vouga

Sara Almeida e Silva / António Manuel S. P. Silva / Paulo A. P. Lemos / Edite Martins de Sá

1127 Castro de Nossa Senhora das Necessidades (Sernancelhe): uma primeira análise artefactual Telma Susana O. Ribeiro

${ }_{1141}$ A cividade de Bagunte. O estado atual da investigação Pedro Brochado de Almeida

1153 Zoomorfos na cerâmica da Idade do Ferro no NW Peninsular: inventário, cronologias e significado Nuno Oliveira / Cristina Seoane

1163 Vasos gregos em Portugal: diferentes maneiras de contar a história do intercâmbio cultural na Idade do Ferro

Daniela Ferreira

1175 Os exotica da necrópole da Idade do Ferro do Olival do Senhor dos Mártires (Alcácer do Sal) no seu contexto regional

Francisco B. Gomes

\section{Antiguidade Clássica e Tardia}

1191 O uso de madeira como combustível no sítio da Quinta de Crestelos (Baixo Sabor): da Idade do Ferro à Romanização Filipe Vaz / João Tereso / Sérgio Simões Pereira / José Sastre / Javier Larrazabal Galarza / Susana Cosme / José António Pereira / Israel Espi

1207 Cultivos de Época Romana no Baixo Sabor: continuidade em tempos de mudança? João Pedro Tereso / Sérgio Simões Pereira / Filipe Santos / Luís Seabra / Filipe Vaz

1221 A casa romana na Hispânia: aplicação dos modelos itálicos nas províncias ibéricas Fernanda Magalhães / Diego Machado / Manuela Martins

1235 As pinturas murais romanas da Rua General Sousa Machado, n. ${ }^{5}$ 1, Chaves José Carvalho

1243 Trás do Castelo (Vale de Mir, Pegarinhos, Alijó) - Uma exploração agrícola romana do Douro

Tony Silvino / Pedro Pereira

1255 A sequência de ocupação no quadrante sudeste de Bracara Augusta: as transformações de uma unidade doméstica Lara Fernandes / Manuela Martins

1263 Os Mosaicos com decoração geométrica e geométrico-vegetalista dos sítios arqueológicos da área do Conuentus Bracaraugustanus. Novas abordagens quanto à conservação, restauro, decoração e datação Maria de Fátima Abraços / Licínia Wrench

1277 “Casa Romana” do Castro de São Domingos (Cristelos, Lousada): Escavação, Estudo e Musealização Paulo André de P. Lemos

1291 A arqueobotânica no Castro de Guifões (Matosinhos, Noroeste de Portugal): O primeiro estudo carpológico

Luís Seabra / Andreia Arezes / Catarina Magalhães / José Varela / João Pedro Tereso 
1305 Um Horreum Augustano na Foz do Douro (Monte do Castelo de Gaia, Vila Nova de Gaia) Rui Ramos

1311 Ponderais romanos na Lusitânia: padrões, formas, materiais e contextos de utilização Diego Barrios Rodríguez

1323 Um almofariz centro-itálico na foz do Mondego

Marco Penajoia

1335 Estruturas romanas de Carnide - Lisboa Luísa Batalha / Mário Monteiro / Guilherme Cardoso

1347 O contexto funerário do sector da "necrópole NO" da Rua das Portas de S. Antão (Lisboa): o espaço, os artefactos, os indivíduos e a sua interconectividade na interpretação do passado Sílvia Loja, José Carlos Quaresma, Nelson Cabaço, Marina Lourenço, Sílvia Casimiro, Rodrigo Banha da Silva, Francisca Alves-Cardoso

${ }_{1361}$ Povoamento em época Romana na Amadora - resultados de um projeto pluridisciplinar Gisela Encarnação / Vanessa Dias

1371 A Arquitectura Residencial em Mirobriga (Santiago do Cacém): contributo a partir de um estudo de caso Filipe Sousa / Catarina Felício

${ }_{1385}$ O fim do ciclo. Saneamento e gestão de resíduos nos edifícios termais de Mirobriga (Santiago do Cacém)

Catarina Felício / Filipe Sousa

1399 Balsa, Topografia e Urbanismo de uma Cidade Portuária Vítor Silva Dias / João Pedro Bernardes / Celso Candeias / Cristina Tété Garcia

1413 No Largo das Mouras Velhas em Faro (2017): novas evidências da necrópole norte de Ossonoba e da sua ocupação medieval Ricardo Costeira da Silva / Paulo Botelho / Fernando Santos / Liliana Nunes

1429 Instrumentos de pesca recuperados numa fábrica de salga em Ossonoba (Faro) Inês Rasteiro / Ricardo Costeira da Silva / Paulo Botelho

1439 A Necrópole Romana do Eirô, Duas Igrejas (Penafiel): intervenção arqueológica de 2016 Laura Sousa / Teresa Soeiro

1457 Ritual, descarte ou afetividade? A presença de Canis lupus familiaris na Necrópole Noroeste de Olisipo (Lisboa)

Beatriz Calapez Santos / Sofia Simões Pereira / Rodrigo Banha da Silva / Sílvia Casimiro / Cleia Detry / Francisca Alves Cardoso

1467 Dinâmicas económicas em Bracara na Antiguidade Tardia Diego Machado / Manuela Martins / Fernanda Magalhães / Natália Botica

1479 Cerâmicas e Vidros da Antiguidade Tardia do Edifício sob a Igreja do Bom Jesus (Vila Nova de Gaia) Joaquim Filipe Ramos

1493 Novos contributos para a topografia histórica de Mértola no período romano e na Antiguidade Tardia Virgílio Lopes

\section{8. Época Medieval}

1511 Cerâmicas islâmicas no Garb setentrional "português": algumas evidências e incógnitas Constança dos Santos / Helena Catarino / Susana Gómez / Maria José Gonçalves / Isabel Inácio / Gonçalo Lopes / Jacinta Bugalhão / Sandra Cavaco / Jaquelina Covaneiro / Isabel Cristina Fernandes / Ana Sofia Gomes 
1525 Contributo para o conhecimento da cosmética islâmica, em Silves, durante a Idade Média Rosa Varela Gomes

1537 Yábura e o seu território - uma análise histórico-arqueológica de Évora entre os séculos VIII-XII José Rui Santos

1547 A encosta sul do Castelo de Palmela - resultados preliminares da escavação arqueológica Luís Filipe Pereira / Michelle Teixeira Santos

1559 A igreja de São Lourenço (Mouraria, Lisboa): um conjunto de silos e de cerâmica medieval islâmica

Andreia Filipa Moreira Rodrigues

1571 O registo material de movimentações populacionais no Médio Tejo, durante os séculos XII-XIII. Dois casos de "sunken featured buildings", nos concelhos de Cartaxo e Torres Novas Marco Liberato / Helena Santos / Nuno Santos

1585 O nordeste transmontano nos alvores da Idade média. Notas para reflexão Ana Maria da Costa Oliveira

1601 Sepulturas escavadas na rocha do Norte de Portugal e do Vale do Douro: primeiros resultados do Projecto SER-NPVD

Mário Jorge Barroca / César Guedes / Andreia Arezes / Ana Maria Oliveira

1619 "Portucalem Castrum Novum" entre o Mediterrâneo e o Atlântico: o estudo dos materiais cerâmicos alto-medievais do arqueossítio da rua de D. Hugo, nํ. 5 (Porto) João Luís Veloso

1627 A Alta Idade Média na fronteira de Lafões: notas preliminares sobre a Arqueologia no Concelho de Vouzela

Manuel Luís Real / Catarina Tente

1641 Um conjunto cerâmico medieval fora de portas: um breve testemunho aveirense Susana Temudo

${ }_{1651}$ Os Lóios do Porto: uma perspetiva integrada no panorama funerário da Baixa Idade Média à Época Moderna em meios urbanos em Portugal

Ana Lema Seabra

1659 O Caminho Português Interior de Santiago como eixo viário na Idade Média Pedro Azevedo

1665 Morfologia Urbana: Um exercício em torno do Castelo de Ourém André Donas-Botto / Jaqueline Pereira

1677 Intervenção arqueológica na Rua Marquês de Pombal/Largo do Espírito Santo (Bucelas, Loures)

Florbela Estêvão / Nathalie Antunes-Ferreira / Dário Ramos Neves / Inês Lisboa

1691 O Cemitério Medieval do Poço do Borratém e a espacialidade funerária na cidade de Lisboa Inês Belém / Vanessa Filipe / Vasco Noronha Vieira / Sónia Ferro / Rodrigo Banha da Silva

1705 Um Espaço Funerário Conventual do séc. XV em Lisboa: o caso do Convento de São Domingos da Cidade Sérgio Pedroso / Sílvia Casimiro / Rodrigo Banha da Silva / Francisca Alves Cardoso

\section{9. Época Moderna e Contemporânea}

1721 Arqueologia Moderna em Portugal: algumas reflexões críticas em torno da quantificação de conjuntos cerâmicos e suas inferências históricas e antropológicas Rodrigo Banha da Silva / André Bargão / Sara da Cruz Ferreira

1733 Faianças de dois contextos entre os finais do século XVI e XVIII do Palácio dos Condes de Penafiel, Lisboa

Martim Lopes / Tomás Mesquita 
1747 Um perfil de consumo do século XVIII na foz do Tejo: O caso do Mercado da Ribeira, Lisboa Sara da Cruz Ferreira / Rodrigo Banha da Silva / André Bargão

1761 Os Cachimbos dos Séculos XVII e XVIII do Palácio Mesquitela e Convento dos Inglesinhos (Lisboa)

Inês Simão / Marina Pinto / João Pimenta / Sara da Cruz Ferreira / André Bargão / Rodrigo Banha da Silva

1775 "Tomar os fumos da erua que chamão em Portugal erua sancta». Estudo de Cachimbos provenientes da Rua do Terreiro do Trigo, Lisboa

Miguel Martins de Sousa / José Pedro Henriques / Vanessa Galiza Filipe

1787 Cachimbos de Barro Caulínitico da Sé da Cidade Velha (República de Cabo Verde)

Rodrigo Banha da Silva / João Pimenta / Clementino Amaro

1801 Algumas considerações sobre espólio não cerâmico recuperado no Largo de Jesus (Lisboa) Carlos Boavida

1815 Adereços de vidro, dos séculos XVI-XVIII, procedentes do antigo Convento de Santana de Lisboa (anéis, braceletes e contas)

Joana Gonçalves / Rosa Varela Gomes / Mário Varela Gomes

1837 Da ostentação, luxo e poder à simplicidade do uso quotidiano: arqueologia e simbologia de joias e adornos da Idade Moderna Portuguesa Jéssica Iglésias

1849 Os amuletos em Portugal - dos objetos às superstições: o coral vermelho Alexandra Vieira

1865 Cerâmicas de Vila Franca de Xira nos séculos XV e XVI Eva Pires

1879 «Não passa por teu o que me pertence». Marcas de individualização associadas a faianças do Convento de Nossa Senhora de Aracoeli, Alcácer do Sal Catarina Parreira / Íris Fragoso / Miguel Martins de Sousa

1891 Cerâmica de Leiria: alguns focos de produção

Jaqueline Pereira / André Donas-Botto

1901 Os Fornos na Rua da Biquinha, em Óbidos Hugo Silva / Filipe Oliveira

1909 A casa de Pêro Fernandes, contador dos contos de D. Manuel I: o sítio arqueológico da Silha do Alferes, Seixal (século XVI) Mariana Nunes Ferreira

1921 O Alto da Vigia (Sintra) e a vigilância e defesa da costa Alexandre Gonçalves / Sandra Santos

1937 O contexto da torre sineira da Igreja de Santa Maria de Loures Paulo Calaveira / Martim Lopes

1949 A Necrópole do Hospital Militar do Castelo de São Jorge e as práticas funerárias na Lisboa de Época Moderna Susana Henriques / Liliana Matias de Carvalho / Ana Amarante / Sofia N. Wasterlain

1963 SAND - Sarilhos Grandes Entre dois Mundos: o adro da Igreja e a Paleobiologia dos ossos humanos recuperados

Paula Alves Pereira / Roger Lee Jesus / Bruno M. Magalhães

1975 Expansão urbana da vila de Cascais no século XVII e XVIII: a intervenção arqueológica na Rua da Vitória no 15 a 17

Tiago Pereira / Vanessa Filipe

1987 Novos dados para o conhecimento do Urbanismo de Faro em época Moderna Ana Rosa 
1995 Um exemplo de Arqueologia Urbana em Alcoutim: o Antigo Edifício dos CTT Marco Fernandes / Marta Dias / Alexandra Gradim / Virgílio Lopes / Susana Gómez Martínez

2007 Palácio dos Ferrazes (Rua das Flores/Rua da Vitória, Porto): a cocheira de Domingos Oliveira Maia

Francisco Raimundo

2021 As muitas vidas de um edifício urbano: História, Arqueologia e Antropologia no antigo Recreatório Paroquial de Penafiel Helena Bernardo / Jorge Sampaio / Marta Borges

2035 O convento de Nossa Senhora da Esperança de Ponta Delgada: o contributo da arqueologia para o conhecimento de um monumento identitário João Gonçalves Araújo / N’Zinga Oliveira

2047 Arqueologia na ilha do Corvo... em busca da capela de Nossa Senhora do Rosário Tânia Manuel Casimiro / José Luís Neto / Luís Borges / Pedro Parreira

2059 Perdidos à vista da Costa. Trabalhos arqueológicos subaquáticos na Barra do Tejo Jorge Freire / José Bettencourt / Augusto Salgado

2071 Arqueologia marítima em Cabo Verde: enquadramento e primeiros resultados do projecto CONCHA

José Bettencourt / Adilson Dias / Carlos Lima / Christelle Chouzenoux / Cristóvão Fonseca / Dúnia Pereira / Gonçalo Lopes / Inês Coelho / Jaylson Monteiro / José Lima / Maria Eugénia Alves / Patrícia Carvalho / Tiago Silva

2085 Trabalhos arqueológicos na Cidade Velha (Ribeira Grande de Santiago, Cabo Verde): reflexões sobre um projecto de investigação e divulgação patrimonial André Teixeira / Jaylson Monteiro / Mariana Mateus / Nireide Tavares / Cristovão Fonseca / Gonçalo C. Lopes / Joana Bento Torres / Dúnia Pereira / André Bargão / Aurélie Mayer / Bruno Zélie / Carlos Lima / Christelle Chouzenoux / Inês Henriques / Inês Pinto Coelho / José Lima / Patrícia Carvalho / Tiago Silva

2103 A antiga fortificação de Quelba / Khor Kalba (E.A.U.). Resultados de quatro campanhas de escavações, problemáticas e perspectivas futuras Rui Carita / Rosa Varela Gomes / Mário Varela Gomes / Kamyar Kamyad

2123 Colónias para homens novos: arqueologia da colonização agrária fascista no noroeste ibérico Xurxo Ayán Vila / José Mạ . Señorán Martín 


\title{
CACHIMBOS DE BARRO CAULÍNITICO DA SÉ DA CIDADE VELHA (REPÚBLICA DE CABO VERDE)
}

\author{
Rodrigo Banha da Silva ${ }^{1}$, João Pimenta ${ }^{2}$, Clementino Amaro ${ }^{3}$
}

\begin{abstract}
RESUMO
Numa cooperação entre as autoridades da República de Cabo Verde e o extinto Instituto Português do Património Cultural, uma escavação arqueológica extensa foi dirigida entre 1989 e 1993 por um dos autores (C.A. - Amaro, 2013) nas ruínas da catedral da antiga cidade da Ribeira Brava.

Os trabalhos revelaram diversos contextos dos séculos XVII e XVIII realcionados com reformas do edifício religioso, providenciando uma valiosa visão sobre a cultura material do período colonial em Cabo Verde. Àparte outras evidências de produtos oleiros europeus, foram recolhidos fragmentos de 21 cachimbos, evocativos das realações comerciais entre o Império Português e outros espaços políticos, igualmente sugestivos da frequência do consumo de tabaco na época.
\end{abstract}

Palavras-chave: Cachimbos cerâmicos, “Cultura Tabágica”, Arqueologia Moderna, Arqueologia Colonial.

\begin{abstract}
The authorities of the Republic of Cape Verde and the former Portuguese institute of heritage (IPPC) cooperate to do an archaeological excavation between 1989 and 1993 in the ruins of the Cathedral of "Cidade Velha", the former main religious spot of the archipelago, under the direction of one of the authors (C.A. - Amaro, 2013). The work revealed several contexts connected with reformations of the religious temple dating from late $17^{\text {th }}$ and $18^{\text {th }}$ century, providing an insight on material culture of the colonial period in Cape Verde Archipelago. Clay tobacco pipe sherds were identified, displaying some data related to commercial links between the Portuguese Empire and other European spaces, as well as suggestive of the frequency of tobacco consumption in Cape Verde at the time.
\end{abstract}

Keywords: Clay Tobacco Pipes, “Tobacco Culture”, Early Modern Archaeology, Colonial Archaeology.

\section{INTRODUÇÃO}

Ao abrigo de um protocolo estabelecido entre as autoridades da cultura da República de Cabo Verde e o então Instituto Português do Património Cultural (IPPC), realizaram-se três campanhas arqueológicas dirigidas por um de nós (C.A.), entre 1989 e 1993, nas ruínas da Sé da Cidade Velha, antiga Ribeira Grande, a primeira capital do arquipélago.

De entre o conjunto de construções da antiga capital colonial de Cabo Verde ao longo da Época Moderna, a Sé resultou de um vector da política de D. João
III de criação de sete novas dioceses, para o que o monarca foi obtendo a necessária autorização papal (Ribeira Grande e Goa - 1533; Angra do Heroísmo - 1534; Miranda do Douro e Leiria - 1545; Portalegre - 1549; São Salvador da Baía-1551 - MIMOSO, 1996: p.10). Os projectos de algumas destas novas catedrais do tipo igreja-salão de três naves mostram as afinidades fortes e evidentes entre as sés da $\mathrm{Ri}$ beira Grande, Portalegre, Leiria e Miranda do Douro (Mimoso, 1996). A construção da Sé da Cidade Velha só seria mais tarde projectada e iniciada somente em 1556-8. Contudo, a despeito de fortemente fi-

\footnotetext{
1. CHAM-FCSH/UNL e Uaç; rbds@fcsh.unl.pt

2.UNIARCH-FLUL; joao.marques@cm-vfxira.pt

3. Associação Olisipo Forum
} 
nanciada, não seria todavia concluída, detendo-se a edificação cerca de 1571 (Mimoso, 1996, p. 16). Deste modo se aproveitaram nos finais do século XVII as paredes externas entretanto esgalgadas para acondicionar um outro modelo arquitectónico de nave única, sendo que a construção por fim se terminaria antes de 1705 (Mimoso, 1996, p. 38)

Em progressivo estado de ruína, a Sé da Cidade Velha seria portanto alvo da intervenção articulada entre as autoridades da cultura da República de Cabo Verde e o extinto IPPC, e iria permitir a reabilitação e consolidação deste espaço emblemático, marcando o início de um conjunto de diversificadas iniciativas e estabelecimento de protocolos de colaboração que se alargaram a vários pontos da antiga cidade (Tavares, 2017), culminando este processo com a classificação da Cidade Velha pela UNESCO como Património Mundial da Humanidade, em 2009, e a reposição do município, com a designação de Ribeira Grande de Santiago.

A intervenção arqueológica na Sé foi centrada, numa primeira fase, no desentulhamento do espaço interior da sé, antecedido pela remoção de cerca de duas centenas e meia de cantarias e elementos arquitetónicos e escultóricos que, nesta fase, são deslocados para o antigo adro da Sé, onde se procedeu ao seu inventário e registo fotográfico.

Com a segunda campanha deu-se início a um conjunto de sondagens, preferencialmente destinadas ao reconhecimento da estabilidade e assentamento das fundações das paredes estruturais e pilares, acção que decorreu em articulação com a equipa de engenharia. Procedeu-se, em simultâneo, à realização sondagens pontuais, como na capela-mor, e uma limpeza e decapagem geral, mais fina, de todo o espaço interior.

Esta acção permitiu a identificação do alinhamento dos pilares de sustentação das três naves do templo, dos alicerces das capelas laterais, lado norte, bem como a definição integral do transepto e do embasamento das torres sineiras, dados disponibilizados à equipa de arquitetura, para retificação do levantamento inicial.

O Gabinete Técnico de apoio à obra, vai ser igualmente utilizado como um depósito visitável de cantarias e elementos escultóricos, entretanto aqui recolhidos, como de doações por parte da população, para além de aqui se proceder ao inventário, tratamento e conservação do espólio cerâmico, dos elementos pétreos, madeiras, ferros, argamassas e espólio osteológico.
Na fase final da intervenção, procedeu-se ao desaterro da envolvente exterior à capela-mor e à recuperação do soco primitivo do edifício, após significativa remoção de aterros. Nesta acção, são recuperados os alicerces e soleiras de porta de duas salas laterais à capela-mor, lado sul, correspondendo à sacristia e sala anexa.

Foi tomada a iniciativa de se proceder ao preenchimento de espaços vazios nas paredes mais altas a fim colmatar uma visível degradação, para o que foi contratado um pedreiro local, familiarizado com a construção de alvenaria em pedra e a utilização de argamassa de base tradicional.

Sendo o território cabo-verdiano sujeito a ventos fortes em determinados meses do ano, e como resultado da ausência dos pisos, que teriam sido em tijoleira, optou-se por cobrir integralmente o espaço interior com areia do rio de origem vulcânica, num diálogo de contrastes entre o tom negro da areia e o tom claro do edificado em calcário.

\section{OS RESULTADOS DA INTERVENÇÃO NA SÉ DA CIDADE VELHA}

Do conjunto dos túmulos identificados nas sondagens abertas junto à face interna das paredes e dos pilares das naves, da maioria já só subsistia o covacho, muitas vezes com a presença ainda de nódulos de cal, e onde o espólio associado se limita a alfinetes do sudário, escassos fragmentos de tecido e várias dezenas contas de rosário. Registámos igualmente dois ossários. Um significativo número de tampas sepulcrais e outros elementos pétreos foram reutilizados na construção de casas, nomeadamente a partir das primeiras décadas do século XX, como constatámos em duas habitações contíguas à Sé.

Foram, no entanto, identificadas três sepulturas com a respetiva tampa lavrada e com dedicatória. Refere-se uma delas ao capitão-mor António José Xavier, falecido em 1755, e uma segunda ao coronel Manuel Dias de Moura, falecido em 1818 e de sua mulher. O grande destaque, no entanto, e com impacto local, foi a identificação da caixa tumular e respetiva tampa sepulcral do primeiro bispo residente de Cabo Verde, D. João Parvi, que foi sepultado na Igreja de Nossa Senhora do Rosário em 1546 e depois trasladado para a sepultura de D. Fr. Vitoriano Portuense, bispo que concluiu as obras da Sé e falecido em 1705. O túmulo encontra-se em posição central na capela-mor e estava ladeado pelo cadeiral. 
No decurso da terceira campanha, na nave lateral norte, foi identificada uma estrutura com planta em U, desalinhada com a orientação da sé e que se interpretou como sendo os alicerces de um pequeno templo que existiu neste local no início do século XVI, fora da cidade, e de invocação a São Sebastião, ficando a sua memória ligada ao nome do bairro onde veio a construir-se a Sé.

O espólio exumado caracteriza-se maioritariamente pela sua modéstia, encontrando-se associado aos enterramentos, nomeadamente das sondagens junto aos pilares, como alfinetes, medalha, contas de rosário em osso e escassas em vidro, e alguns numismas. Na torre sul foi recuperada uma pulseira em prata e coral, e na torre norte uma tampa em bronze de vaso litúrgico.

O único local identificado com uma diversidade de espólio algo significativo, correspondeu ao aterro que nivelou, em certo momento, o espaço compreendido entre o embasamento dos degraus de acesso ao altar e a parede de fundo da capela-mor.

A sondagem revelou uma vasta profusão de materiais em deposição secundária, oriundos duma presumível lixeira. Do conjunto, destacamos a presença de porcelana da China, faiança portuguesa e espanhola e, presumivelmente, italiana, loiça vidrada, cerâmica modelada e pedrada, alguma cerâmica comum de ir à mesa, base de fogareiro, anforetas de produção andaluza, algumas marcas de jogo e um pequeno conjunto de cachimbos, objeto do presente estudo.

Proveniente ainda do aterro de nivelamento, destaca-se um significativo conjunto de cerâmica de tradição africana, fabricada ao torno lento ou de modelagem manual, a partir da técnica do rolo, e de cozedura redutora (Amaro, 2013).

Em termos globais, o espólio exumado é enquadrável num período entre a segunda metade do século XVI até finais do século XVII.

Da modesta coleção de numismas exumados no decurso da intervenção, e que apresenta uma cronologia de meados do século XVI à $1^{\mathrm{a}}$ República, merecem destaque III reis de D. Pedro II (1699) exumados na sondagem de acesso ao túmulo do bispo, sendo passível de associar este achado com o momento de trasladação do primeiro bispo de Cabo Verde (Amaro, 2013).

\section{O CONJUNTO DE CACHIMBOS RECO- LHIDO NAS ESCAVAÇÕES DE 1989-1993 DA SÉ DA CIDADE VELHA}

O conjunto é formado por 28 fragmentos atribuíveis a um mínimo de 21 exemplares de cachimbo produzidos com argilas caulínicas. Entre estes contam-se duas porções decoradas da haste e 8 fragmentos conservando parte ou a totalidade do fornilho, elementos mais qualificados para uma atribuição cronológica e de origem. Entre os indivíduos encontram-se quatro ostentando marcas no pedúnculo que permitem situar com total segurança os respectivos oleiros e/ou centros produtores, ilustrando no momento a exclusividade no local de produções holandesas e britânicas, igualmente discerníveis através da tipologia das decorações das hastes e das morfologias dos fornilhos.

Dos diversos contextos onde foram exumados fragmentos de cachimbo, apenas para os achados relacionados com a capela-mor se poderá propor uma cronologia, já que os materiais que se encontram associados, apontam para datações entre a segunda metade do século XVI até finais do século XVII. As obras de conclusão da Sé também reforçam esta data limite, já que as mesmas terão terminado em finais do século XVII. Em sentido contrário, os elementos cronológicos proporcionados pelos cachimbos não contradizem esta leitura produzida com base estratigráfica.

\subsection{Catálogo}

1. Fragmento de haste de cachimbo em cerâmica. Fragmento da parte mesial da haste, de secção ovalada e mostrando vestígios do alisamento externo, preservando $45 \mathrm{~mm}$ de comprimento. O perfil mostra muito ligeira tendência convergente e arqueada. A pasta é caulínica, um pouco granulosa, de coloração branca e tonalidade amarfinada.

Dimensões: espessura mín. $=6,7 \mathrm{~mm}$; espessura máx. $=7,8 \mathrm{~mm}$; diâmetro do orifício int. $=3 \mathrm{~mm}$. Indicações contextuais: Altar-Mór / Corredor Sul / Altar (n.․ Inv: CV/90/15).

2. Fragmentos de haste de cachimbo em cerâmica. Dois fragmentos com colagem da parte mesial da haste, de secção quase circular e mostrando vestígios do alisamento externo, com algumas estrias, preservando $65 \mathrm{~mm}$ de comprimento. Como o an- 
terior, o perfil mostra ligeira tendência convergente e arqueada.

Pasta similar ao número anterior.

Dimensões: espessura mín. $=7 \mathrm{~mm}$; espessura máx. $=7,7 \mathrm{~mm}$; diâmetro do orifício int. $=3,1 \mathrm{~mm}$.

Indicações contextuais: Altar-Mór / Corredor Sul / Altar (n..$^{\circ}$ Inv: CV/9o/11462).

3. Fragmento de haste de cachimbo em cerâmica. Fragmento da parte mesial da haste, de secção circular, com vestígios do alisamento externo, preservando $43 \mathrm{~mm}$ de comprimento. O perfil mostra-se ligeiramente convergente.

Pasta similar à dos números anteriores.

Dimensões: espessura mín $=7 \mathrm{~mm}$; espessura máx. $=7,8 \mathrm{~mm}$; diâmetro do orifício int. $=2,7 \mathrm{~mm}$.

Indicações contextuais: Altar-Mór / Decapagem do A.M. (n. ${ }^{\circ}$ Inv: CV/89/7478).

4. Fragmento de haste de cachimbo em cerâmica. Fragmento da parte mesial da haste, de secção circular, com vestígios do alisamento externo, preservando $22 \mathrm{~mm}$ de comprimento. O perfil mostra-se ligeiramente convergente.

Pasta similar à dos números anteriores, um pouco alterada na superfície.

Dimensões: espessura $=9,2 \mathrm{~mm}$; diâmetro do orifício int. $=2,9 \mathrm{~mm}$.

Indicações contextuais: Capela-Mór/ Enchimento da caixa central (n.. Inv: CV/89/7071).

5. Fragmento de haste de cachimbo em cerâmica. Fragmento da parte mesial da haste, de secção circular, com vestígios do alisamento externo, preservando $56 \mathrm{~mm}$ de comprimento. O perfil mostra-se ligeiramente paralelo.

Pasta similar à dos números anteriores. A superfície apresenta-se esbocelada.

Pode fazer parte do mesmo cachimbo apresentado de seguida.

Dimensões: espessura $=5,7 \mathrm{~mm}$; diâmetro do orifício int. $=2,0 \mathrm{~mm}$.

Indicações contextuais: Torre Sul / G15 / plano o / Camada 1 (s/n.․․ Inv.).

6. Fragmento de haste de cachimbo em cerâmica. Fragmento da parte mesial da haste, de secção circular, com vestígios do alisamento externo, preservando $28 \mathrm{~mm}$ de comprimento. O perfil mostra-se ligeiramente convergente.
Pasta similar à dos números anteriores, um pouco alterada na superfície.

Pode fazer parte do mesmo cachimbo apresentado antes.

Dimensões: espessura $=5,8 \mathrm{~mm}$; diâmetro do orifício int. $=2,4 \mathrm{~mm}$.

Indicações contextuais: Torre Sul / G15 / plano o / camada 1 (s/n. ${ }^{\circ}$ Inv.).

7. Fragmento de haste de cachimbo em cerâmica. Fragmento da parte mesial da haste, de secção circular, com vestígios do alisamento externo, com estrias, preservando $29 \mathrm{~mm}$ de comprimento. O perfil mostra-se paralelo.

Pasta similar à dos números anteriores.

Dimensões: espessura $=6,2 \mathrm{~mm}$; diâmetro do orifício int. $=2,0 \mathrm{~mm}$.

Indicações contextuais: Sepultura 1 / F18 E (n. ํำ Inv: CV.SÉ 1-198).

8. Fragmento de haste de cachimbo em cerâmica. Fragmento da parte distal da haste, de secção circular, com vestígios do alisamento externo, preservando $22 \mathrm{~mm}$ de comprimento. O perfil mostra-se paralelo, com marcada divergência na parte mais distal da junção com o formilho.

Pasta depurada, de coloração acinzentada clara, mostrando textura granulosa e fractura nítida.

Dimensões: espessura $=9,2 \mathrm{~mm}$; diâmetro do orifício int. $=2,0 \mathrm{~mm}$.

Indicações contextuais: Quadrícula P13 / Camada 1 (n.. Inv: CV.SÉ/ PB 1-2).

9. Fragmento de haste de cachimbo em cerâmica. Fragmento da parte distal da haste, de secção circular, com vestígios do alisamento externo, preservando $40 \mathrm{~mm}$ de comprimento. O perfil mostra-se convergente.

Pasta depurada, granulosa, de coloração branco-marfim.

Dimensões: espessura $=8$, o mm; diâmetro do orifício int. $=3,1 \mathrm{~mm}$.

Indicações contextuais: Pilar F / Camada 2 (n.ํ Inv: CV.SÉ/3-206).

10. Fragmento de haste de cachimbo em cerâmica. Fragmento da parte mesial da haste, de secção quase circular, com vestígios do alisamento externo, preservando $40 \mathrm{~mm}$ de comprimento. O perfil mostra-se paralelo. 
Pasta como a do número anterior.

Dimensões: espessura $=9,4 \mathrm{~mm}$; diâmetro do orifício int. $=2,9 \mathrm{~mm}$.

Indicações contextuais: Descontextualizado (n..$^{\circ}$ Inv: CV.SÉ/3-195).

11. Fragmento de haste de cachimbo em cerâmica.

Fragmento da parte distal da haste, de secção circular, com vestígios do alisamento externo, preservando $44 \mathrm{~mm}$ de comprimento. O perfil mostra-se paralelo, com marcada divergência na parte mais distal da junção com o formilho.

Pasta como a dos números anteriores, mas com as superfícies um pouco alteradas.

Dimensões: espessura = 9,9 mm; diâmetro do orifício int. $=3,0 \mathrm{~mm}$.

Indicações contextuais: Pilar F / Camada 2 (n. ํㅡㄴ CV.SÉ/3-50).

12. Fragmento de haste de cachimbo em cerâmica. Fragmento da parte mesial da haste, de secção circular, com vestígios do alisamento externo, preservando $53,5 \mathrm{~mm}$ de comprimento. O perfil mostra-se paralelo. A superfície externa mostra uma decoração alternando circulos e denticulados, impressa com roletilha. Este tipo de ornamentação da haste foi usada intensivamente pelos fabricantes de Gouda (Países Baixos) entre os séculos XVII e XIX. Todavia, as características da haste denunciam uma elaboração que poderá datar de 169o, pelo menos, sendo admissível datas de até c.1780, pelo mais (DUCO, 2003: pp. 204-207).

Pasta como a dos números anteriores.

Dimensões: espessura $=7,5 \mathrm{~mm}$; diâmetro do orifício int. $=2,4 \mathrm{~mm}$.

Indicações contextuais: Sacristia/ Camada 2 (desentulhamento) (S/n.o Inv).

13. Fragmento de haste de cachimbo em cerâmica. Fragmento da parte distal da haste, de secção circular, com vestígios do alisamento externo, preservando 53,5 mm de comprimento. O perfil mostra-se ligeiramente divergente, mais acentuado na zona de junção com o fornilho. A superfície externa mostra uma decoração impressa com punção, com flor-de-lis inscrita em losângo delimitado por cercadura, repetida por quatro vezes e com disposição em cruz, denotando vestígios da repetição deste tipo de decoração de que restou somente a parte superior de um outro losângo com a parte superior da flor-de-lis.
A morfologia da haste, em particular as suas dimensões, como a temática ornamental, apontam para tratar-se de uma elaboração oriunda da cidade holandesa de Gouda, com maior probabilidade datada de cerca de 1640/1650 (DUCO, 2003: pp. 202-203). Pasta como a dos números anteriores.

Dimensões: espessura $=9,4 \mathrm{~mm}$; diâmetro do orifício int. $=3,0 \mathrm{~mm}$.

Indicações contextuais: Altar-Mór / Camada 2 (desmontagem) (n.ํo Inv: CV.SÉ/3-23).

14.Fragmento de fornilho e haste de cachimbo em cerâmica.

Fragmento conservando parte do fornilho, dotade de pedúnculo cilíndrico, também truncado, e da parte distal terminal da haste, de secção de tendência ovalada, com vestígios do alisamento externo, preservando aquela $36,5 \mathrm{~mm}$ de comprimento. $O$ perfil da haste é quase paralelo, mas ligeiramente divergente da zona terminal distal para a mesial.

Pasta como a dos números anteriores.

Dimensões: espessura da haste $=9,5 \mathrm{~mm}$; diâmetro do orifício int. $=2,9 \mathrm{~mm}$.

Indicações contextuais: Altar-Mór / Camada 2 (desmontagem) (n.ํo Inv: CV.SÉ/3-22).

15. Fragmento de fornilho de cachimbo em cerâmica. Fragmento conservando parte do fornilho.

Pasta como a dos números anteriores.

Indicações contextuais: Nave lateral Sul / G17 / plano o / Camada i (S/n.o Inv.).

16. Fragmento de fornilho de cachimbo em cerâmica. Fragmento conservando o fornilho, em "forma de túlipa”, e vestígios do arranque da haste. Na face externa da boca ostenta decoração de filete executado com roletilha fina. O pedúnculo é baixo e quase circular, ostentando a marca executada a punção RT. Pasta similar à dos números anteriores.

Dimensões: altura máxima $=31,7 \mathrm{~mm}$; diâmetro interno da boca: 13,1 mm.

Indicações contextuais: Quadrícula P13 / Camada 1 (n. ${ }^{\circ}$ Inv: CV.PB 1-3).

17. Fragmento de fornilho de cachimbo em cerâmica. Fragmento conservando a parte inferior do fornilho, em "forma de túlipa", o arranque da haste. Esta é de secção ovalada, preservando somente $4,4 \mathrm{~mm}$ de comprimento. O pedúnculo é baixo e quase circular, ostentando a marca executada a punção AL/+. 
Pasta similar à dos números anteriores.

Dimensões: altura máxima preservada $=29,1 \mathrm{~mm}$; espessura máxima da haste $=11,4 \mathrm{~mm}$; diâmetro do orifício int. $=2,6 \mathrm{~mm}$.

Indicações contextuais: sem indicação.

18. Fragmento de fornilho de cachimbo em cerâmica. Fragmento conservando parte do fornilho, em "forma de túlipa" alta, e vestígios do arranque da haste. $\mathrm{Na}$ face externa da boca ostenta decoração de filete executado com roletilha fina. O pedúnculo é baixo e oval, isento de marca. A morfologia do fornilho, caracteristicamente holandesa, aponta para uma cronologia em torno de 1640/1650 (Duco, 2003: p. 203). Pasta similar à dos números anteriores.

Dimensões: altura máxima =34,3 mm; diâmetro interno da boca: 12,8 $\mathrm{mm}$.

Indicações contextuais: Sem indicação (n. ํ. Inv: CV.SÉ 3-24).

19. Fragmento de fornilho de cachimbo em cerâmica. Fragmento conservando o fornilho, alto e em forma de campânula, com vestígios do arranque da haste. Na face externa da boca mostra desbaste resultante de afeiçoamento no momento do fabrico. O pedúnculo é alto e cilíndrico. Na face esquerda do pedúnculo mostra marca em relêvo composta por três pontos circulares alinhados. A haste era de secção circular. Pasta similar à dos números anteriores.

Dimensões: altura máxima $=38,4 \mathrm{~mm}$; espessura máxima da haste $=8,3 \mathrm{~mm}$; diâmetro do orifício int. $=2,2 \mathrm{~mm}$.

Indicações contextuais: Pilar F / Camada 2 (n.ำ Inv: CV.SÉ 3-51).

20. Fragmento de fornilho de cachimbo em cerâmica. Fragmento da boca e parede de fornilho, alto e em forma de campânula. A boca ostenta decoração de filete fino executado a roletilha.

Pasta similar à dos números anteriores.

Dimensões: altura máxima conservada =c. $43 \mathrm{~mm}$. Indicações contextuais: Quadrícula P13 / Camada 1 (n. ${ }^{\circ}$ Inv: CV.PB 1-4).

21. Fragmentos de fornilho de cachimbo em cerâmica. Fragmentos conservando a totalidade do fornilho, alto e em forma de campânula, com vestígios do arranque da haste. Na face externa da boca mostra decoração de filete fino executado a roletilha. O pedúnculo é alto e cilíndrico. Em ambas as faces do pe- dúnculo estão patentes as armas da cidade de Gouda encimadas pela letra S. A base do pedúnculo mostra a marca impressa a punção com o numeral 54, coroado. A haste era de secção circular.

Pasta similar à dos números anteriores.

Dimensões: altura máxima $=54,0 \mathrm{~mm}$; espessura máxima da haste $=$ c. $8,0 \mathrm{~mm}$; diâmetro do orifício int. $=1,7 \mathrm{~mm}$.

Indicações contextuais: Quadrícula F16 Sul / plano o / camada 1 (s/n..$^{\circ}$ Inv.).

\subsection{Marcas e fabricantes}

O n. ${ }^{\circ} 16$ (Figura 7, n. ${ }^{1}$ 16), equivale a uma produção marcada "RT não coroado" de Gouda, nos Países Baixos, correspondendo ao punção do fabricante de cachimbos Rogier Tonstal, activo entre 1637/1640 e 1654/166o (Duco, 1982; 2003, p. 167).

O n. ${ }^{\circ} 17$ (Figura.7, n.․ำ 17 ostenta a marca AL/+. Trata-se de impressão usada em fabricos sediados em Chester (Inglaterra), estratigraficamente situados no lapso 1630-1680 (Rutter \& Davey, 1980). No caso presente, a morfologia do fornilho e a impressão enquadram-se no lapso de 1640-1680 (Rutter \& Davey, 1980, p. 217).

19, por seu turno, equivale a um tipo de marca presente em várias produções europeias, sem que se lhe possa atribuir categoricamente uma origem a partir do punção. A morfologia do fornilho, todavia, sugere um fabrico inglês datado dos finais do século XVII. Já o n.ำ 21 ostenta em ambas as laterais do pedúnculo as armas da cidade de Gouda (Países Baixos), encimada pela letra $S$, que lhe atestava a qualidade inferior. Na base foi aplicado o punção com o numeral "54 coroado", utilizado durante um período longo pelos fabricantes da cidade holandesa, entre 1685 e 1940 (Duco, 2003, p. 193). Dentro deste lapso de tempo, 7 fabricantes usaram o punção, sendo de excluir todos os que não são compatíveis com a cronologia denunciada pela morfologia do fornilho, setecentista. Deste modo se apura dever corresponder a um produto fabricado por Dirck de Jong, que laborou entre 1685 e 1728 (Duco, 2003, p. 193).

\section{CONSIDERAÇÕES FINAIS}

O pequeno conjunto de 21 indivíduos recolhidos nas escavações arqueológicas da Sé da cidade antiga da Ribeira Grande (Cidade Velha), capital colonial do arquipélago de Cabo Verde durante a Época Moderna, permite um conjunto de inferências rele- 
vantes quer quanto às conexões comerciais mantidas pelo arquipélago, quer em relação aos contornos sociais do consumo do tabaco nos séculos XVII e XVIII em Cabo Verde.

O consumo do tabaco mediante o uso de cachimbo é um fenómeno onde a Inglaterra e a Holanda jogam um papel fundamental, aí se iniciando a partir dos inícios do último quartel do século XVI o fabrico em escala do objecto, não se estranhando por isso a ausência de execplares com estas cronologias nos contextos arqueológicos cabo-verdianos. Os dados da Sé, aliás, parecem corroborar o panorama reinol, em particular lisboeta, onde os dados de maior antiguidade parecem não remontar com anterioridade a cerca de 1630/1640 ((Pimenta, Calado \& Silva, 2008; Calado et al., 2013).

É a partir do segundo terço do século XVII que o registo arqueológico da Sé assinala e atesta a disseminação do consumo tabágico mediante cachimbo cerâmico, que além disso regista uma predominância seiscentista em resultado da própria estratigrafia exumada, fortemente condicionada pela história da Sé que, recorde-se, somente se inaugura algures entre 1699 e antes de 1705.

Ora, é do maior interesse arqueológico situar esta atestação de cachimbos em relação ao conhecimento histórico existente da população da cidade da Ribeira Grande, de maneira a se aferir o perfil social do consumo atestado pela arqueologia...

Assim, na transição do século XVI para o século XVII, após a deslocação do centro nevrálgico do comércio escravo de Cabo Verde para a costa continental africana, inicia-se um processo de decadência urbana com o abandono dos armadores e grandes comerciantes, formando-se na cidade da Ribeira Grande uma outra camada social composta por intermediários comerciais, tais como feitores e procuradores de grandes mercadores reinóis, pequenos parceiros de mercadores estrangeiros (Cabral, 1995). Neste quadro se verifica, in absentia, a ascensão de uma elite mestiça, de tal forma que à chegada dos Jesuítas, em 1617 se declara que na composição do concelho camarário "chegou a terra a tais termos que quantos ha hoje na Câmara são crioulos" (Arsi, Lus., Cód. 74, fls. 141-143 v, 27 de Junho de 1617 in Brásio, 1968: p. 613. apud Cabral et al. 2012: p. 8), uma nova elite urbana de um aglomerado que passara dos 500 vizinhos nos meados do séc. XVI a 15/16 brancos de Portugal e 35 da terra, crioulos, em 1630 (excluindo-se escravos, decerto pouco numerosos -
Cabral et al. 2012). É portanto a esta composição social, incluindo aqui os escravos africanos da Ribeira Grande, que se deverá cometer o uso dos cachimbos exumados na Sé da Cidade Velha.

Afortunadamente, as evidências arqueológicas cabo-verdianas apontam categoricamente para o cachimbo e o consumo tabágico se terem disseminado no século XVII aos mais variados níveis sociais, devendo-se a este propósito invocarem-se os dados valiosos colectados no "concheiro" da Baía de Salamansa, na Ilha de São Vicente pelas escavações de João Luís Cardoso, onde se identificou um fundo de cabana com o mesmo tipo de associação material presente na Sé da Cidade Velha, e que incluía três cachimbos cerâmicos cauliníticos, dois dos quais equivalentes a porções com fornilho do séc. XVII, de provável fabrico britânico (Cardoso \& Soares, 2010:, p. 198, fig. 27 e p. 199).

$\mathrm{O}$ acesso pela comunidade da Cidade Velha às importações britânicas e holandesas, no caso da Sé comprovadas por uma impressão de Chester (Inglaterra) e três de Gouda (Países Baixos), não surpreende, dado o carácter de importante escala desempenhado por Cabo Verde em Época Moderna no âmbito da navegação triangular atlântica. A atestação cabo-verdiana pode, contudo, reflectir no todo ou em parte um fenómeno muito mais amplo. Não se tendo conseguido aceder a mais dados de natureza arqueológica, o exemplo estudado do entreposto dinamarquês de Christiansborg Castle (Gana) revelou uma presença muito numerosa de cachimbos desde os finais do século XVII, que só se pode justificar pelo seu uso instrumental no comércio esclavagista praticado pelos escandinavos do Golfo da Guiné (Engmann, 2018). Sintomaticamente, o registo manuscrito de um navio negreiro danês de 1770, assinala que o vaso transportava 360 "cachimbos longos" e 228 "cachimbos de escravos", destinados a serem distribuídos pelo capitão um a cada escravo, a que se acrescentava uma dose diária de tabaco-excepto aos sábados- ao longo de todo o trajecto da viagem até ao continente americano (Handler, 2009, p. 9 apud Engmann, 2018, p. 48). É admissível que o tipo de prática fosse bem mais generalizado pelos negreiros dos séculos XVII e XVIII e que seja por essa via o cachimbo tenha sido incorporado nos hábitos das populações cabo-verdianos.

O uso de cachimbo entre a comunidade da Ribeira Grande, portanto, terá constituído um traço da "bricolage cultural" operacionalizada no aglomerado 
urbano da Ilha de Santiago, um elemento da composição do "patchwork cultural" (para usar aqui felizes expressões a um outro muito distinto propósito inauguradas por Nicola Terranato - 1998) que caracteriza a identidade cabo-verdiana seiscentista.

\section{BIBLIOGRAFIA}

AMARO, Clementino (2013) - "Sé da Cidade Velha, República de Cabo Verde”, in A.Teixeira e J Bettencourt (coord.), Velhos e Novos Mundos, Estudos de Arqueologia Moderna, vol. 1. Lisboa, Centro de História de Além Mar, pp.452-464.

BRÁSIO, António (1968) - Monumenta Missionária Africana, 2ª̣ . série, vol. IV. Lisboa, Agência Geral do Ultramar.

CABRAL, Iva (1995) - "Ribeira Grande: vida urbana, gente, mercancia, estagnação”, in Maria Emília Madeira Santos (coord.) História Geral de Cabo Verde. Lisboa, Instituto de Investigação Nacional, vol. II, pp. 225-274.

CABRAL, Iva; SANTOS, Maria Emília Madeira; SOARES, Maria João; TORRÃO, Maria Manuel Ferraz (2012) - Cabo Verde, uma experiência colonial acelerada (séculos XVI-XVII). http://www.portaldoconhecimento.gov. cv/bitstream/10961/358/1/Cabo\%2oVerde\%2oUma\%20 Experi\%C3\%A Ancia\%2oColonial\%2oAcelerada\%2o \%28Sec.XVI-VII\%29.pdf [Consultado a 09-03-2020]

CALADO, Marco; PIMENTA, João; FERNANDES, Lidia; MARQUES, António (2013) - Os cachimbos cerâmicos do Palácio Marialva", in Revista Portuguesa de Arqueologia. Lisboa: 16, pp. 383-392.

CARDOSO, João Luís; SOARES, António Manuel Monge (2010) - "A estação arqueológica de Salamansa (ilha de São Vicente, República de Cabo Verde)". Revista Portuguesa de Arqueologia: 13. Lisboa, pp. 167-214.

DUCO, Don H. (1982) - Merken van Goudse Pijpenmakers 166o-1940. Amsterdam: Pijpenkabinet.

DUCO, Don H. (2003) - Merken in merkenrecht van de pijpenmakers in Gouda. Amsterdam: Pijpenkabinet.

ENGMANN, Rachel Ama Asaa (2018) - "Dutch Clay Smoking Pipes from Christiansborg Castle, Ghana, West Africa”. Society for Clay Pipe Research Newsletter: 93 - 40-52.

MIMOSO, Alexandre Brás (2016) - “Interpretação e consolidação da Sé da Cidade Velha em Cabo Verde", Sumara. Cidade da Praia: Fundação João Lopes, ano II, n.. 2 (https://www. academia.edu/39530791/Interpreta\%C3\%A7\%C3\%A30_e_ consolida\%C3\%A7\%C3\%A3O_da_S\%C3\%A9_da_Cidade_ Velha_em_Cabo_Verde) [Consultado a 09/03/202O].

PIMENTA, João; CALADO, Marco; SILVA, Rodrigo Banha da (2008) - "Cachimbos de cerâmica provenientes da escavação do Caminho da Ronda no Castelo de São Jorge, Lisboa" , in Hélder Abraços e João Diogo (Eds.) Actas das $4^{\underline{a}} \mathrm{~s}$ Jornadas de Cerâmica Medieval e Pós-Medieval (Tondela, 2000). Tondela: Câmara Municipal de Tondela, pp. 335-353.
RUTTER, Janet; DAVEY, Peter (1980) - 'Clay pipes from Chester', in P. Davey (ed.) The Archaeology of the clay tobacco pipe III Britain: the north and west. Oxford, BAR British Series: 78, pp. 40-272.

TAVARES, Nireide Pereira(2017) - Inventário Arqueológico de Cabo Verde: contributo para uma ferramenta de gestão e valorização do Património Cultural. Lisboa: Universidade de Lisboa, Faculdade de Letras (dissertação de mestrado - https://repositorio.ul.pt/bitstream/10451/28730/1/ ulfl234009_tm_Vol-\%20I.pdf) [Consultado a 10/o6/2020].

TEIXEIRA, André; BETTENCOURT, José(coord.) (2013) VelhoseNovosMundos,EstudosdeArqueologiaModerna,vol.1. Lisboa, Centro de História de Além Mar.

TERRANATO, Nicola (1998) - “The Romanization of Italy: Global Acculturation or Cultural Bricolage?”, in TRAC 97: Proceedings of the Seventh Annual Theoretical Roman Archaeology Conference, Nottingham 1997. Oxford: Oxbow Books, pp. 20-27. 


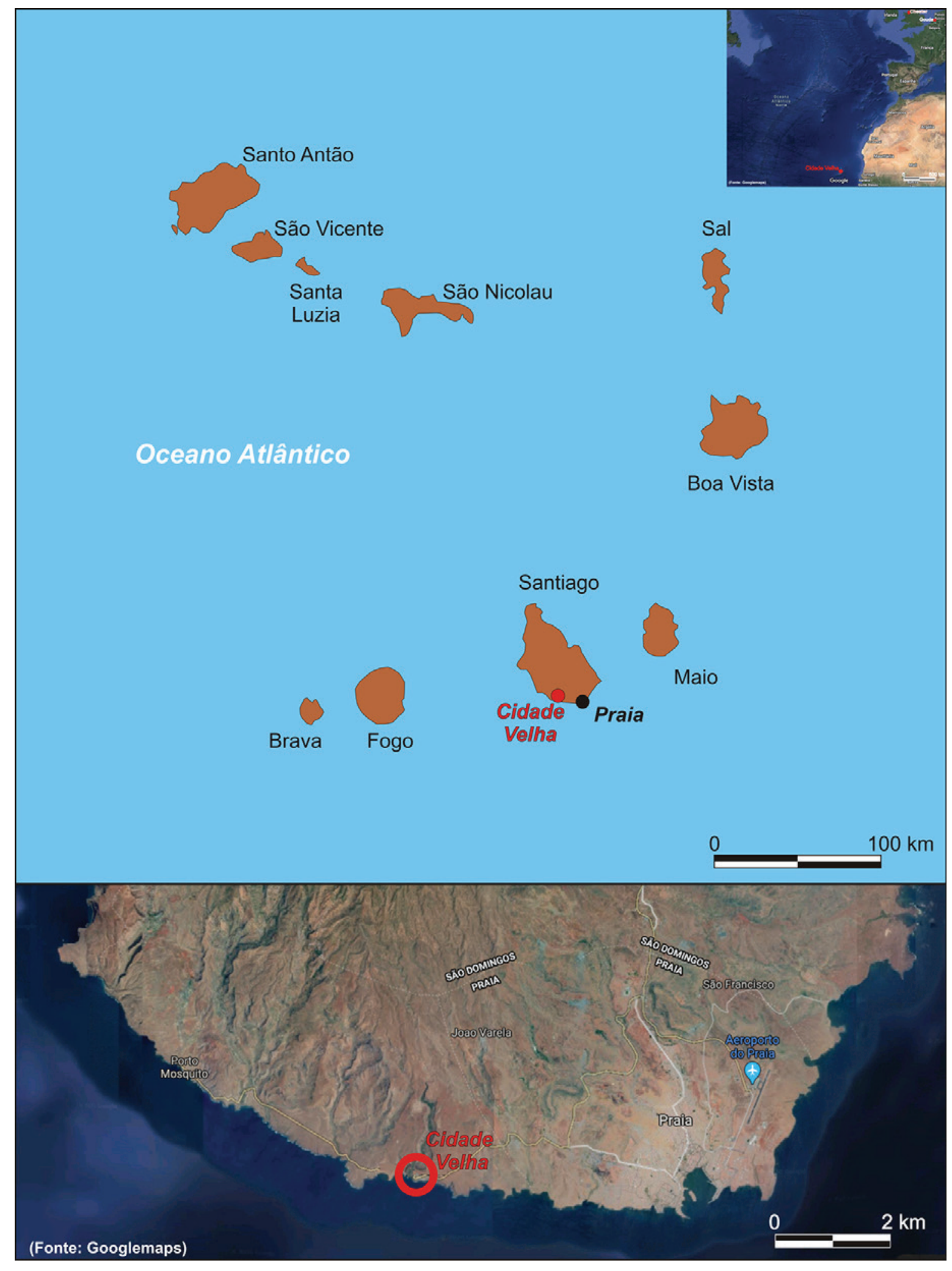

Figura 1 - República de Cabo Verde e sul da Ilha de Santiago com localização da Cidade Velha. 


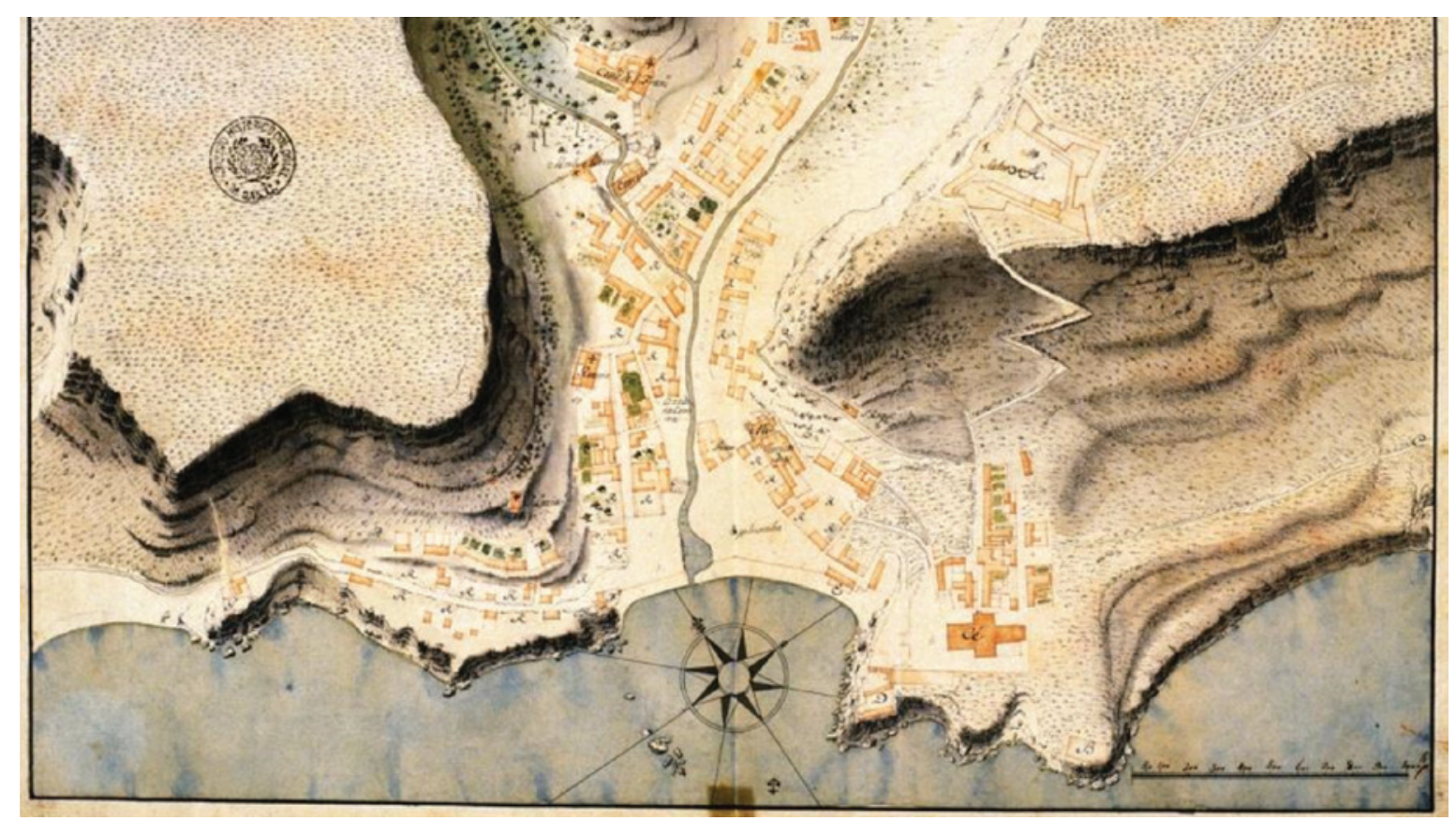

Figura 2 - Planta da Cidade de Ribeira Grande ("Cidade Velha) de José Carlos Andreias, 1769 (Arquivo Histórico Ultramarino, s/n.o). (Segundo Mimoso, 2016, p. 39, fig.27).

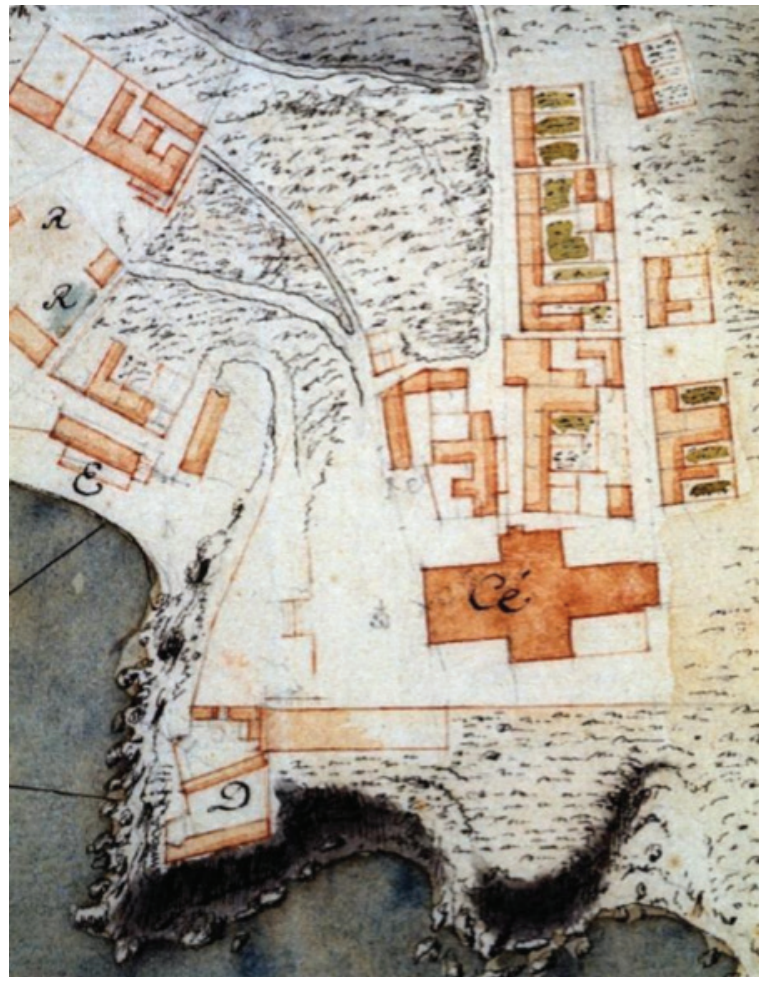

Figura 3 - Detalhe da planta anterior com a localização da Sé (Idem: p. 39, fig. 28).

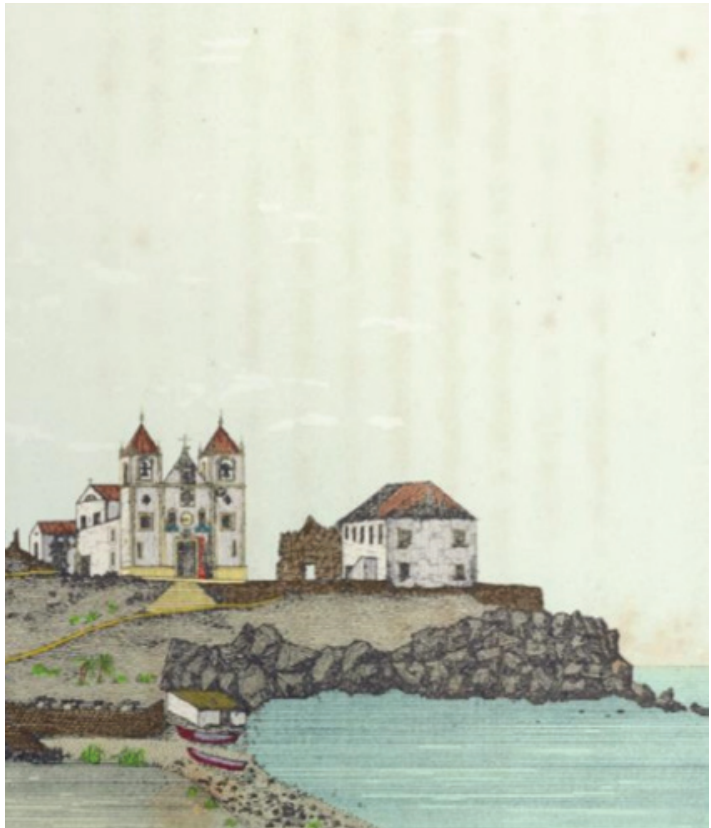

Figura 4 - Detalhe com a fachada da Sé de gravura de Francico Travassos Valdez, 1869 (Idem: p. 43, fig. 29). 


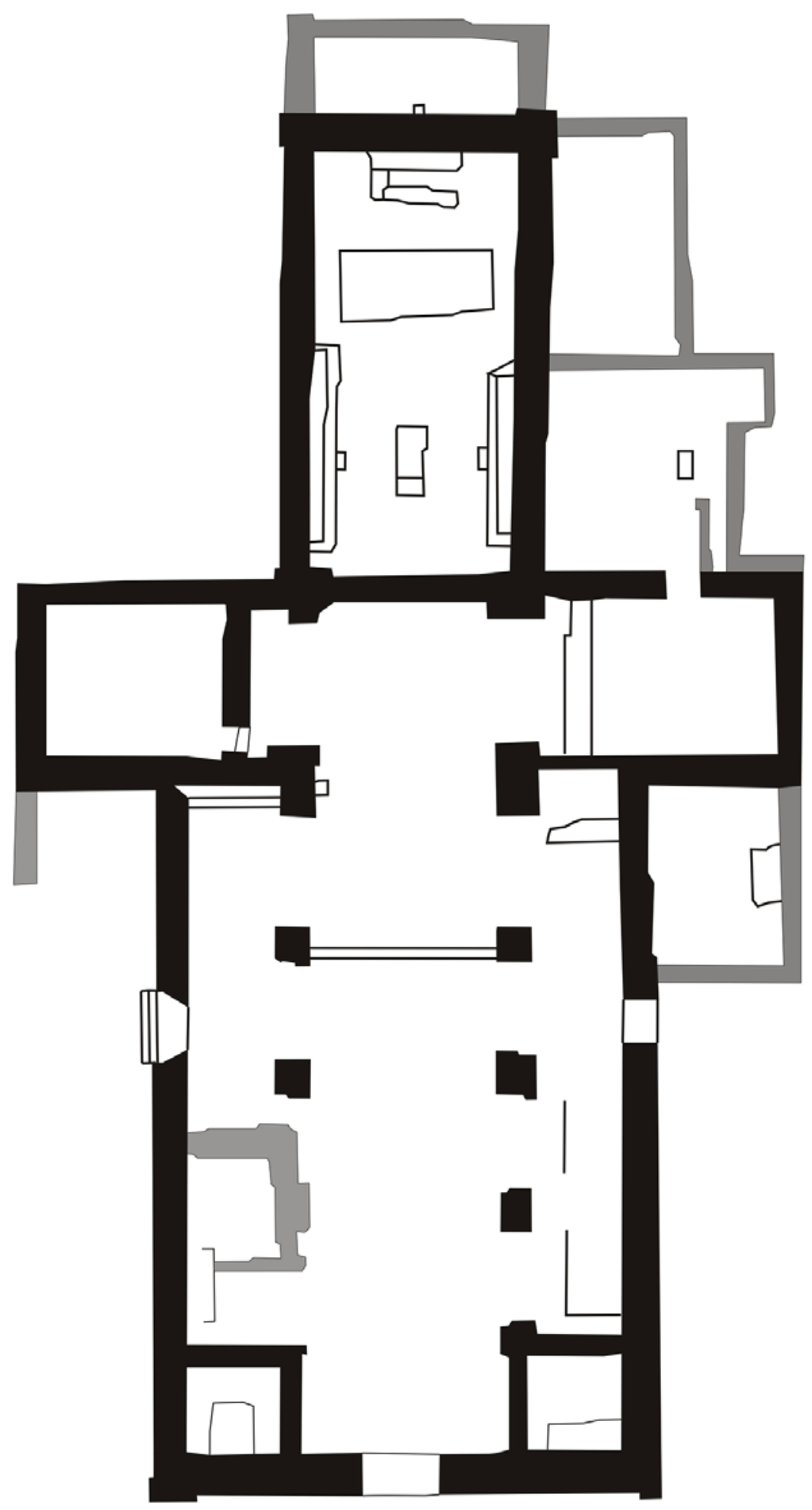

Figura 5 - Planta simplificada da Sé da Cidade Velha (Segundo levantamento da Univ. Beira Interior, adaptada). 

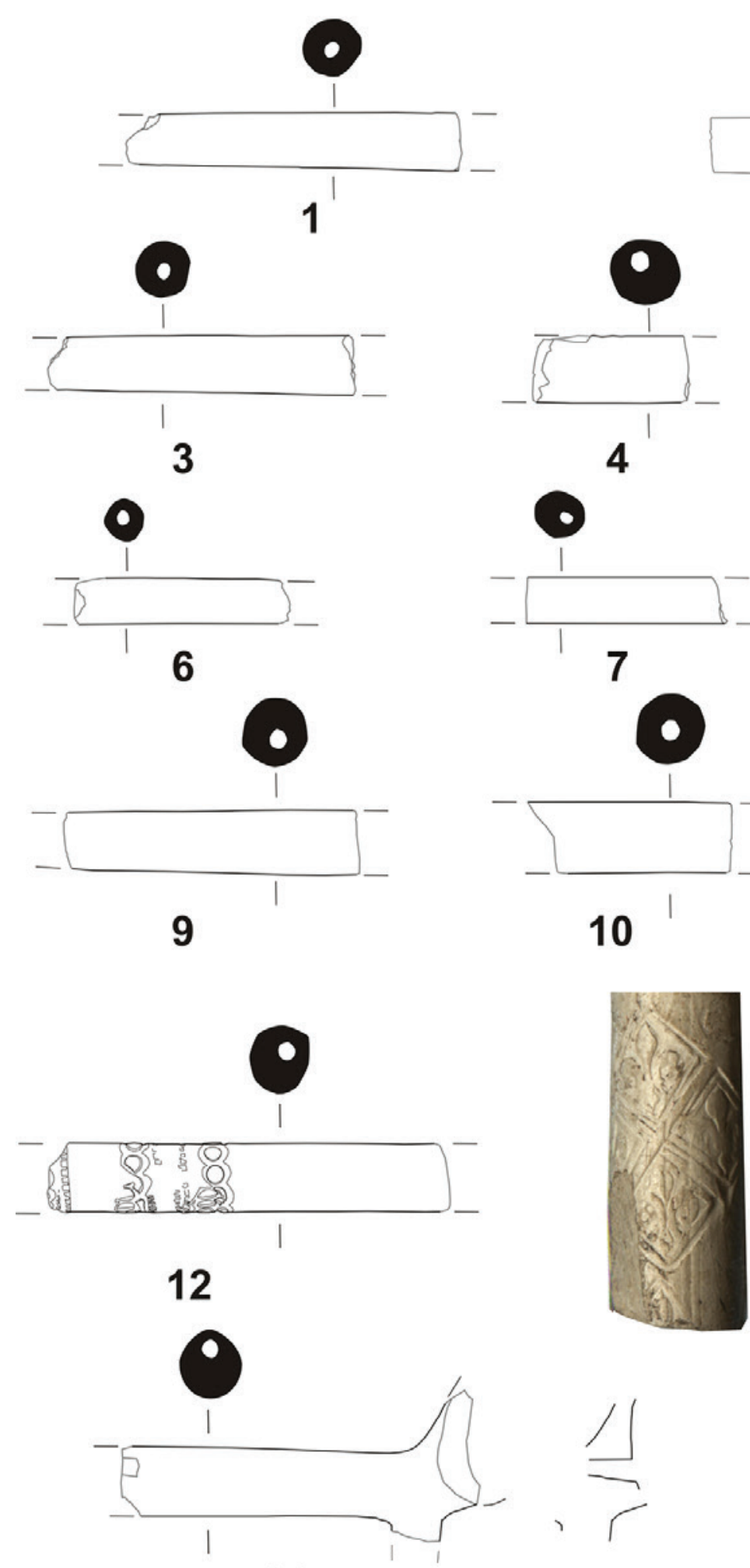

14
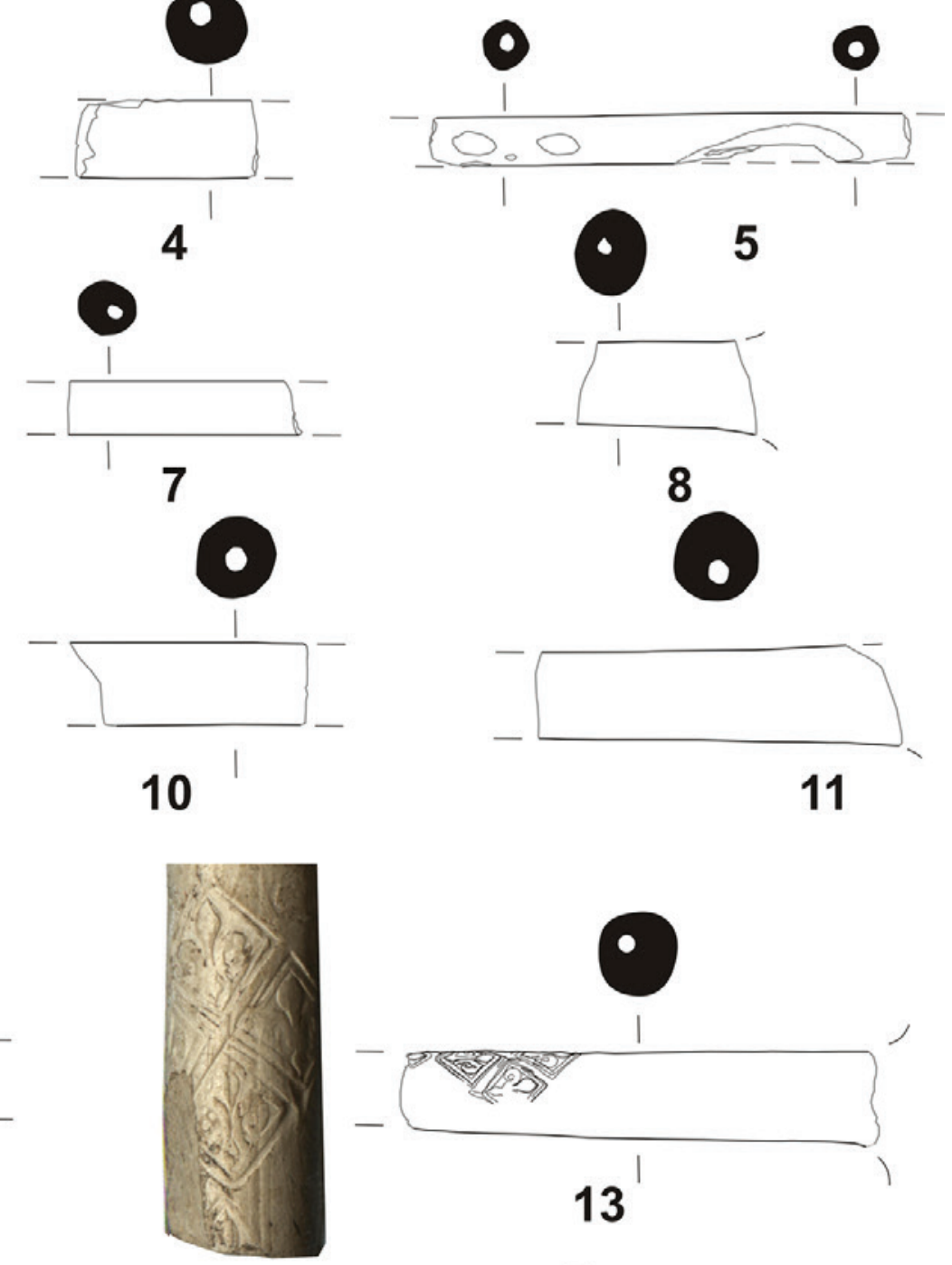

Esc.1/1 (foto 2/1)

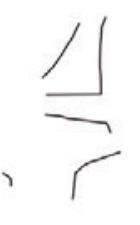

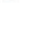



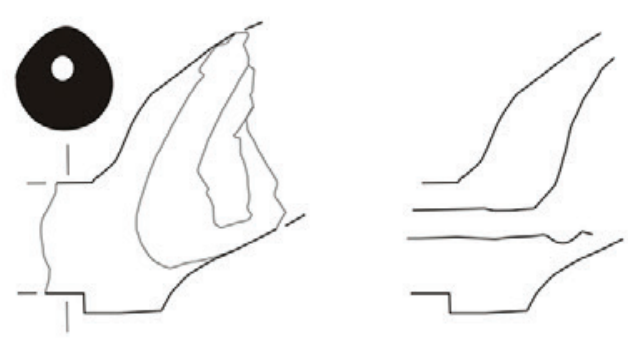

16
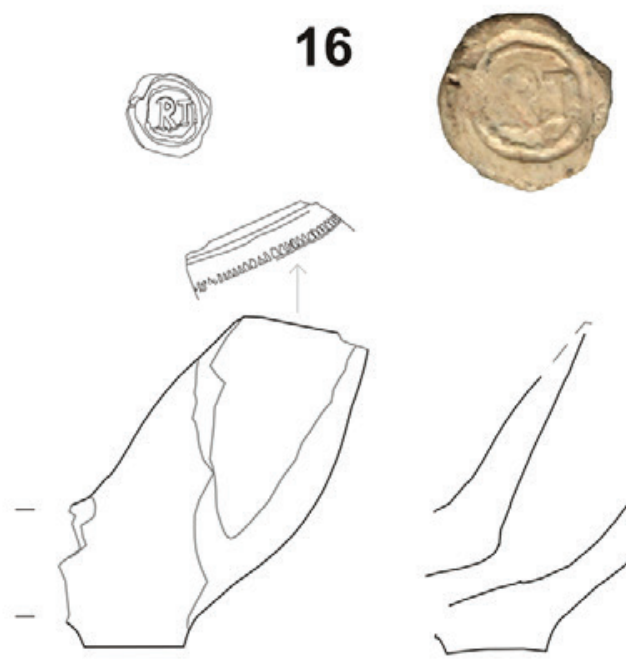

18

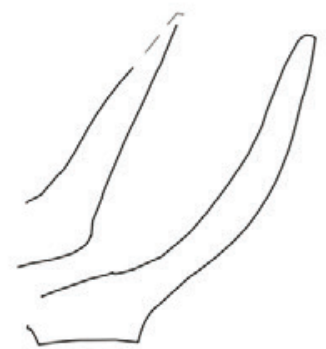

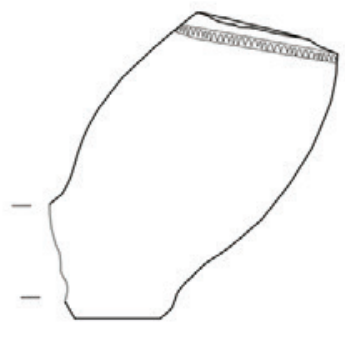
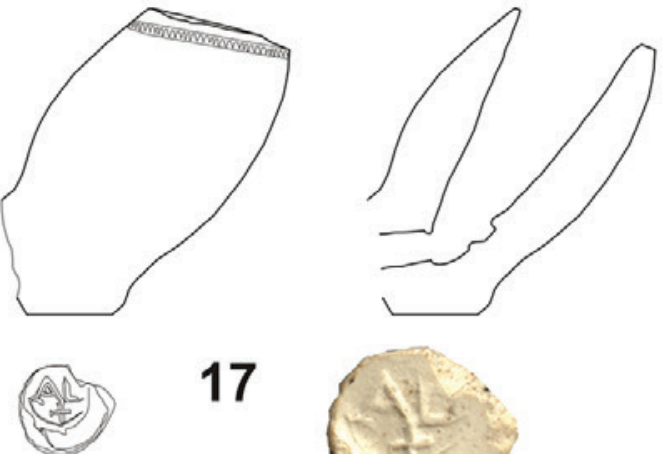

17
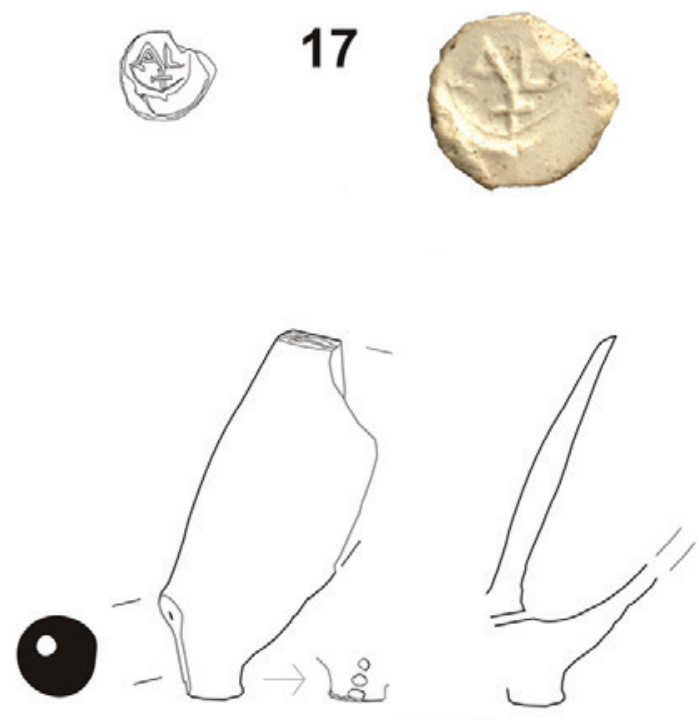

19

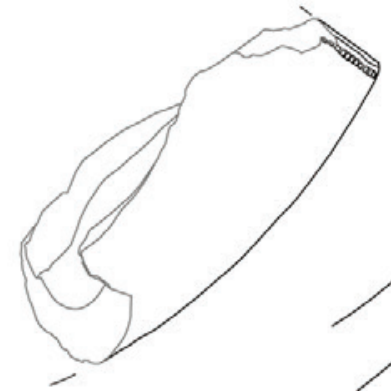

20

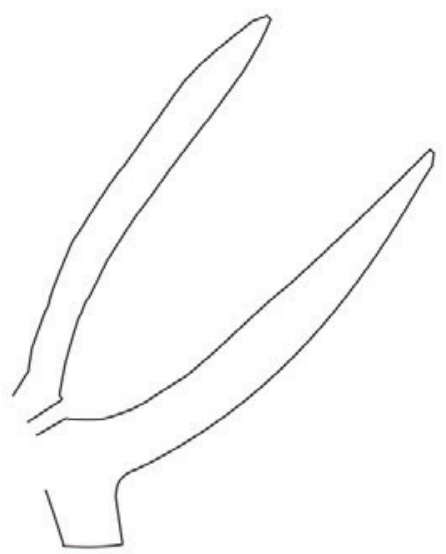

Esc.1/1 (fotos 2/1)
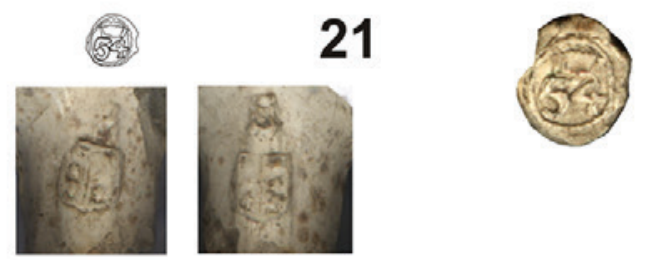

$5 \mathrm{~cm}$

Figura 7 - Fragmentos de fornilho de cachimbos em cerâmica caulínica das escavações de 1989-1993 da Sé da "Cidade Velha" (República de Cabo Verde). 


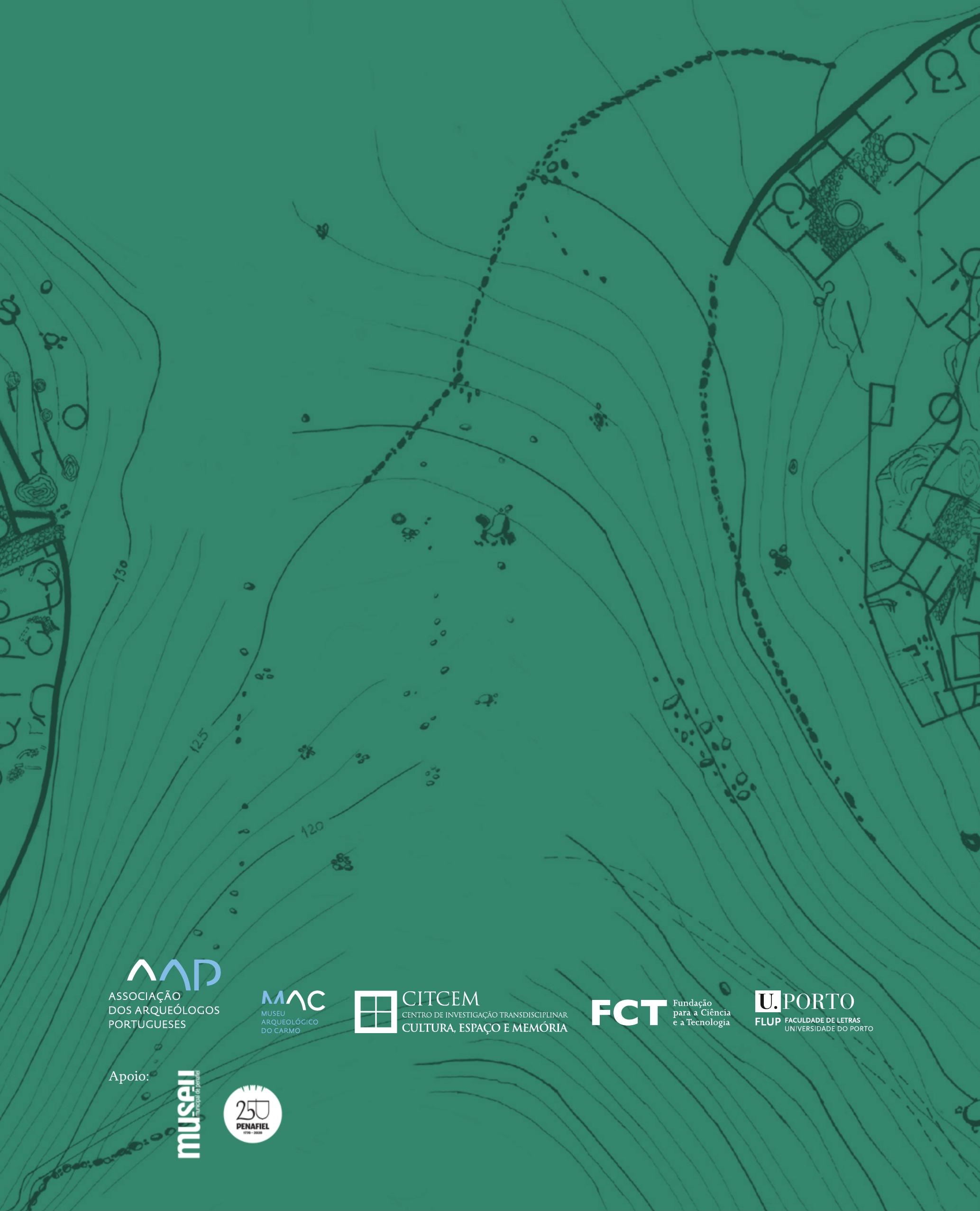

